Policy Research Working Paper 2026

Circuit Theory of Finance and the Role of Incentives in Financial Sector Reform

Biagio Bossone
This study analyzes the role of finance in the context of a circuit model and shows how the financial system complements the price mechanism in coordinating decentralized intertemporal resource allocation choices by agents operating with limited information and incomplete trust. The study identifies incentives to improve the efficiency and stability of financial circuits in emerging economies.

The World Bank

Financial Sector Practice Department

Financial Economics Unit

December 1998

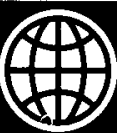


Policy Research Working Paper 2026

\section{Summary findings}

Bossone analyzes the financial system's role in economic growth and stability, addressing several core policy issues associated with financial sector reform in emerging economies. He studies finance's role in the context of a circuit model, with interacting rational, forward-looking, heterogeneous agents.

He shows finance to essentially complement the price system in coordinating decentralized intertemporal resource allocation choices made by agents operating with limited information and incomplete trust.

$\mathrm{He}$ discusses the links between finance and incentives for efficiency and stability in the context of the circuit model. He also identifies incentives and incentivecompatible institutions for reform strategies for financial sectors in emerging economies. Among his conclusions:

(1) Circuit theory features important methodological advantages to analyze the role of finance, and to assess structural weaknesses of financial systems under different institutional settings and in diffeerent stages of economic development.

(2) Incentives for prudence and honesty can protect the stability of the circuit by directing private sector forces unleashed by liberalization. In particular:

- Financial institutions should be encouraged to invest in reputational capital.
- Governments should complement the creation of franchise value by strengthening supervision and by adopting a regulatory regime based on rules designed to align the private incentives of market players with the social goal of financial stability.

- Safety nets to reduce systemic risk should minimize the moral hazard from stakeholders by limiting risk protection and by making the cost of protection sensitive to the risk taken.

- Governments should encourage self-policing in the financial sector.

- Where information and trust are scarce, there is a potential market for them, and governments can greatly improve incentives for optimal provision of information.

- Governments should strengthen the complementarity between the formal and the informal financial sectors.

Emphasizing incentives is not to deny the importance of good rules, capable regulators and supervisors, and strong enforcement measures. It is to suggest that the returns on investments to set up rules, institutions, and enforcement mechanisms can be greater if market players have an incentive to align their own objectives with the social goal of financial stability.

This paper is a product of the Financial Economics Unit, Financial Sector Practice Department. Copies of the paper are available free from the World Bank, $1818 \mathrm{H}$ Street NW, Washington, DC 20433. Please contact Biagio Bossone, room MC10-619, telephone 202-473-3021, fax 202-522-2031, Internet address bbossone@worldbank.org. December 1998. (55 pages)

The Policy Research Working Paper Series disseminates the findings of work in progress to encourage the exchange of ideas about development issues. An objective of the series is to get the findings out quickly, even if the presentations are less than fully polished. The papers carry the names of the authors and should be cited accordingly. The findings, interpretations, and conclusions expressed in this paper are entirely those of the authors. They do not necessarily represent the view of the World Bank, its Executive Directors, or the countries they represent. 


\title{
Circuit theory of finance and the role of incentives in financial sector reform
}

\author{
by \\ Biagio Bossone \\ World Bank
}

\begin{abstract}
Summary
This paper analyzes the role of the financial system for economic growth and stability, and addresses a number of core policy issues for financial sector reforms in emerging economies. The role of finance is studied in the context of a circuit model with interacting rational, forwardlooking, and heterogeneous agents. Finance is shown to essentially complement the price system in coordinating decentralized intertemporal resource allocation choices from agents operating under limited information and incomplete trust. The paper also discusses the links between finance and incentives to efficiency and stability in a circuit context. It assesses the implications for financial sector reform policies and identifies incentives and incentive-compatible institutions for financial sector reform strategies in emerging economies.
\end{abstract}

The author is intellectually indebted to the work of Prof. Augusto Graziani in the field of monetary circuit theory. The author wishes to thank Jerry Caprio, Stjin Claessens, and Larry Promisel for their helpful comments on earlier drafts of the paper. He bears full responsibility for any remaining errors and for the opinions expressed in the text. The author is especially grateful to his wife Ornella for her invaluable support. For comments, contact Biagio Bossone, E-mail: Bbossone@worldbank.org, tel. (202) 473-3021, fax (202) 522-2031. 


\section{TABLE OF CONTENTS}

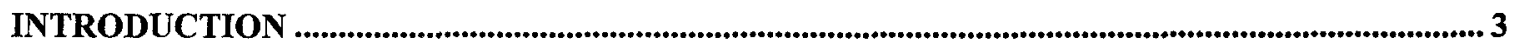

\section{FINANCE IN A MARKET ECONOMY …........................................................................................... 4}

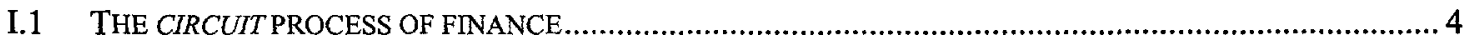

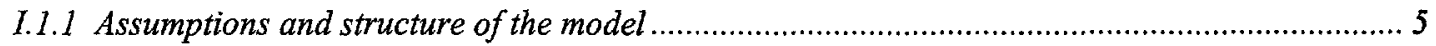

I.1.2 Structural implications of CTF .......................................................................................... 10

I.1.3 Efficiency and stability implications of CTF: the role of incentives ........................................ 14

I.1.4 Theoretical and methodological features of CTF ............................................................. 16

I.2 FINANCE, GROWTH, AND STABILITY: BRIEF CONCEPTUALIZATION AND RECENT EVIDENCE..................17

II. FINANCIAL SECTOR REFORMS IN EMERGING ECONOMIES .................................................. 20

II.1 CTF AND INCENTIVE-BASED FINANCIAL SECTOR REFORMS..........................................................20

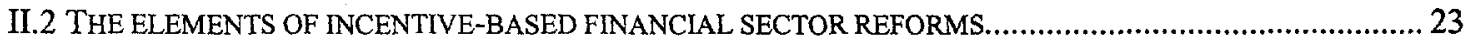

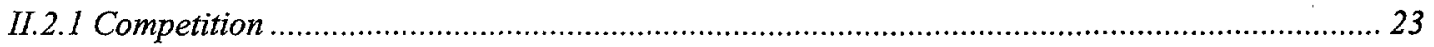

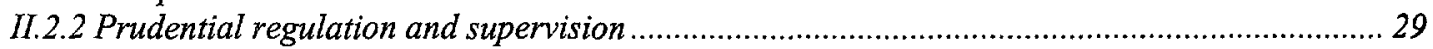

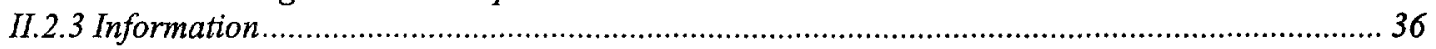

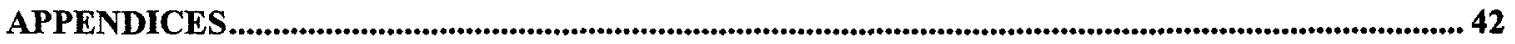

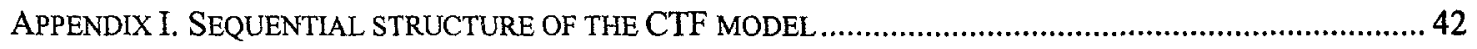

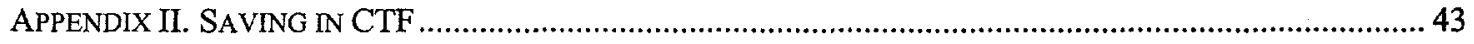

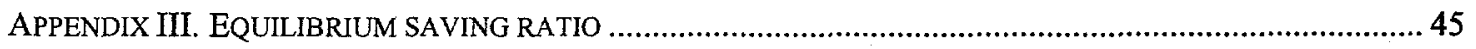

APPENDIX IV. RESOURCE RE-APPROPRIATION BY FIRMS IN THE CIRCUIT PROCESS UNDER EARLY

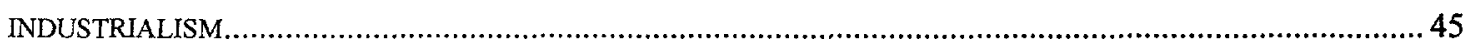

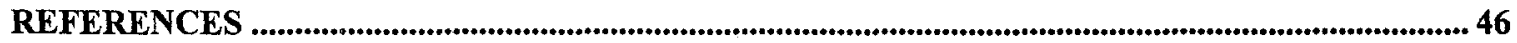




\section{Introduction}

Financial sector reform has gained center stage in current international economic policy debates. This certainly owes to the serious repercussions of the financial crisis that erupted in East Asia last year, as it should be expected to occur whenever critical financial events in a country or a region raise fears that market reactions could provoke widespread contagion. But the centrality of the issue has to do with a deeper reason, that is, the understanding of the crucial role that finance plays for the functioning of market monetary economies of production. Recent economic research has provided important theoretical and empirical elements to such understanding. More progress can be gained by further exploring the implications of the time dimension in the economic process. This will be one of the undertakings of this paper.

The paper analyzes the role of finance for economic growth and stability, and draws policy indications for financial sector reforms in emerging economies. Issues relating to financial crisis management problems and corporate governance are not dealt with in the paper as these are the subject of two recent World Bank policy studies (Claessens, 1988; Prowse, 1998).

The paper is structured in two parts. Part I analyzes the role of finance in a market monetary economy of production: Section I.1 presents a circuit model of the financial system and illustrates the main structural, theoretical and incentive-related policy implications of circuit theory of finance. Section I.2 discusses the special role of the financial system as the core of the circuit process, and reports on recent empirical evidence. Part II focuses on policy issues: based on part I findings, section II.1 makes a case for improving incentives in financial sectors of market-oriented emerging economies, and section II. 2 draws elements for incentive-based financial sector reforms. 


\section{Finance in a market economy}

\section{I.1 The circuit process of finance}

Recognition of finance as a central determinant of accumulation in the development process of a capitalist economy dates back to the works of Hilferding, Keynes, Schumpeter, and Kalecki. Common to their different theories was the vision of the economy as a sequential process where credit needs to be extended to enterprises, and money advanced to workers, for production, investment and exchange to be possible. In fact, Wicksell had placed finance at the core of economic analysis already in the late 1800's by describing the circuit structure of a credit economy. But it was not until the relation between finance and investment was explored by the cited authors, and until Keynes' unconventional view of aggregate saving was formulated in the General Theory and in subsequent writings (Keynes 1936, 1937a, 1937b), that a link could be established between production, finance and investment in a circuit framework.

Over the last twenty-five years, the link has been studied more systematically by monetary circuit theory ${ }^{1}$, which analyzes the properties of the circuit process of a monetary production economy where money is created through credit by banks and provides unique (transaction) services. The theory studies how production, capital accumulation, and income distribution are fundamentally affected by the creation and use of fiat-money. Crucial to this purpose is the functional separation that the theory operates between banks and firms.

The macroeconomic focus of the theory, however, leaves the essential microeconomic aspects of finance out of the picture. In particular, although recognizing time as a fundamental determinant of the circuit, the theory does not draw the implications that uncertainty and incomplete trust - as corollaries of time - bear for finance. The theory thus does not address crucial questions such as why and how financial institutions exist and operate, nor does it concerns itself with the consequences for the circuit process of different financial structures. Moreover, the theory places relatively more emphasis on the monetary phase of the circuit, where liquidity is injected in the system and starts the circuit, than on the financial structural implications of economic sequential processes.

Significant positive and normative progress can be achieved by attempting to lay the ground for a circuit theory of finance incorporating a microeconomic dimension. By framing finance in an integrated structure, circuit theory helps to better identify causes and mechanisms of breakdowns in market financial relationships, and to select ways that minimize their chance of occurrence through appropriate incentives.

This section presents a circuit model of finance with rational, forward-looking and heterogeneous agents, interacting under limited information and incomplete trust. The model is used to show the features that characterize finance once time is introduced in a meaningful way within production, investment, and exchange The circuit structure of the model is based on Davidson's (1991) definitions of investment financing and investment funding (Box 1), which will be used throughout the text. ${ }^{3}$ Whereas monetary-circuit- theory models typically focus on banks as circuit starters and liquidity providers ${ }^{4}$, the finance-circuit-theory model presented here emphasizes the role of investment financial institutions as crucial to ensure the closure of each circuit rounds and to determine the conditions under which new circuit rounds start. This they 
allow to do by reconciling decisions from savers and fund-users, as well as from investing companies and capital good producing firms.

\section{Box 1. Investment financing and investment funding in the circuit process}

Davidson (1991) illustrates the investment-saving process as characterized by the following stylized sequence of steps:

1. Companies that want to add to their physical capital stock (investing companies) place orders of new equipment with capital good producers, and enter into contracts that require them to issue payments to capital good producers upon order delivery

2. Commercial banks extend short-term credit to capital good producers to finance production by issuing new deposits (investment financing)

3. Capital good producers use the new money to advance payments to workers and suppliers

4. Savings accumulate in the economy as wage payments are issued and new incomes are generated

5. Investing companies seek to raise accumulated savings by issuing liabilities with a maturity structure correlated with the income time-profile expected from the new investment; they use the funds raised to settle their contractual obligations with the capital good producers upon delivery (investment funding)

6. Capital good producers use the cash proceeds to pay out their short-term debt with the banking system

7. The circuit may start anew with new short-term bank credit extended to capital good producers for new production.

In fact, the circuit may start with capital good producers undertaking production based on expected investment demand. This, of course, raises the possibility of imbalances taking place between investment demand and supply (see section. II.1.2).

\section{I.1.1 Assumptions and structure of the model}

The model includes four sectors: firms, households, banks, and the capital market. All variables are expressed in monetary terms. Representative firm $f$ produces consumption commodity $c$ and capital good $I$; household $i$ provides middleman services ${ }^{5}$, and household $k$ supplies labor services. At the beginning of the period, firm $f$ borrows credit CR from the banking system and employs labor services from household $k$ at total wage cost $w_{k}$. Production technology of $f$ has constant returns (allowing for profits to be linearly related to supply). Although implicit in this model, prices are assumed to ensure a positive margin on costs. At the end of the period, firm $f$ repays its short-term bank debt with its sale proceeds. Household $i$ buys (wholesale) $c_{w}$ from $f$, resells it (retail) to household $k\left(c_{k}\right)$, and uses the proceeds to finance consumption and saving ( $c_{i}$ and $s_{i}$, respectively). Household $k$ 's labor supply is linear in leisure (i.e. it varies proportionately to wage earnings), spends income $w_{k}$ to purchase $c_{k}$, and saves the remainder. Capital good $I$ is purchased by firms (investing companies) that wish to add to their original productive capacity. Investing companies fund investments with long-term borrowings or equity from the capital market. Aggregate saving provides long-term funds to the capital market. 
Financial investment institutions compete in the capital market to attract funds; they screen and select potential fund-users on the basis of creditworthiness, assess the quality, risk, and profitability of investment projects, allocate funds, monitor their use, and seek to enforce contract obligations. They manage savings on behalf of savers, and may invest their own money as well. Formally, the model is as follows:

\section{Households}

(2) $\quad c_{k}=y_{k}-s_{k}$

(3) $c_{w}=\alpha c_{k}$

$$
0<\alpha<1
$$

(4) $c_{i}=y_{i}-s_{i}$

(5) $y_{k}=w_{k}=w_{c k}+w_{I k}$

$$
\begin{array}{ll}
s_{j=i, k}=s_{j}\left(y_{j}, r_{L}\right) & s_{y}>0, s_{r}>0 \\
s_{j}=s_{j}\left[z_{j}\left(r_{L}, v\right)+1-z_{j}(., .)\right] & 0 \leq z_{j} \leq z^{-} \leq 1 ; z_{1}>0, z_{2}<0 \\
r=z_{j} r_{L} &
\end{array}
$$

Household $i$ 's income is given by i's revenue minus costs (eq.1); $i$ 's revenue is determined by $k$ 's consumption (eq. 2), and $i$ 's costs correspond to its wholesale purchases of $c_{w}$ (eq. 3), which in turn are a fixed proportion of sales $c_{k}$ (as the latter incorporate distribution services value added). Identity (5) defines $k$ 's wage earnings as the sum of work compensations for production of goods $c$ and $I$. Individual household savings are positive in both the rate of return on saving, $r$, and income (eq. 6), consistent with intertemporal utility maximization (see below).

Households invest a share $z$ of their savings in long-term assets by placing money with investment financial institutions in the capital market, and hold the remaining share in noninterest bearing, short-term bank deposits (eq. 7). The share of savings going to the capital market is positive in the long-term rate of interest, $r_{L}$, and negative in the agents' perceived uncertainty, $v$, as to the future states of the economy. Note, however, that demand for long-term assets can be rationed by investment financial institutions (see below), as reflected by term $z^{-}$in (7). The overall return on household saving is a weighted average of the rates of return on individual assets (eq. 8). The model includes rational, forward-looking, interacting households that maximize their lifetime consumption utility subject to an intertemporal budget constraint. Interactions and the sequential nature of the economy play a crucial role in the formation process of saving in the economy. The assumption of intertemporal utility maximization allows for interactions to be modeled within a framework where each household optimizes the information on other agents' behavior, and discriminates optimally between temporary and permanent changes in the economy. Formally, the household plans are:

$$
\operatorname{Max}_{c \geq 0} U=E\left[\sum_{t}^{\infty} \beta^{t} u\left(c_{t}\right)\right], \text { s.t. }
$$

$$
A_{t+1}(1+r)^{-1}-A_{t}=s_{t}
$$


and to transversality condition

(6c) $\lim _{t \rightarrow \infty} A_{t}=0$

where $\mathrm{A}$ is non-human wealth; $\mathrm{u}(\cdot)$ is a (well-behaved) utility function, and $0<\beta<1$ is the time discount factor. Solving plan (6a)-(6c) with dynamic programming, after substituting from the model the appropriate equations for consumption, and noting from eqs. (1) and (2) that $y_{i}=\gamma c_{k}$, where $\gamma=1-\alpha$, yields the Euler conditions for interacting households $i$ and $k$ :

$$
\begin{array}{ll}
i: & \phi_{i}\left[\gamma\left(w_{k t}-s_{k t}\right)-s_{i t}\right]=(1+r) E \beta\left\{\phi_{i}\left[\gamma\left(w_{k t+1}-s_{k t+1}\right)-s_{i t+1}\right]\right\} \\
k: & \phi_{k}\left(w_{k t}-s_{k t}\right)=(1+r) E \beta\left[\phi_{k}\left(w_{k t+1}-s_{k t+1}\right)\right]
\end{array}
$$

where $\phi(\cdot)=u^{\prime}(\cdot)$ is the instantaneous marginal utility of consumption.

\section{Firms}

$$
\begin{array}{ll}
\text { (9) } w_{c k}=v_{c}\left(c_{w}+c_{i}\right)=v_{c} c^{s} & 0<v_{c}<1 \\
\text { (10) } c^{s}=\sum_{j=i, k} c_{j}=c & \\
\text { (11) } w_{l k}=v_{I} I^{s} & 0<v_{I}<1 \\
\text { (12) } I^{s}=E\left[I^{d}\right] & \\
\text { (13) } I^{d}=I^{d}\left(\mu-r_{L}^{-}\right) & I^{\prime}>0 \\
\text { (14) } \mu=\mu\left(K_{0}+I\right) & \mu^{\prime}<0 \\
\text { (15) } y_{f}=I+c-w_{k} &
\end{array}
$$$$
\text { (12) } I^{s}=E\left[I^{d}\right]
$$$$
\text { (14) } \mu=\mu\left(K_{0}+I\right)
$$$$
\text { (16) } y_{f}^{n}=y_{f}-C R\left(1+r_{s}\right)
$$

Wage components are fixed proportions of outputs $c$ and $I$, respectively (eqs. 9 and 11), Consumption good output matches actual demand (eq. 10), while capital good production equal expected demand (eq. 12). According to eq. (13), the demand for capital good $I$ is increasing in the difference between the marginal efficiency of capital $\mu$ and the gross rate of return on longterm funds $r_{L}^{-}$(that is, including intermediation fees - see below). Eq. (14) says that $\mu$ is decreasing in the aggregate real capital $K$ (determined as inherited capital plus new investment). The gross income of $f$ is given by the proceeds from its output sales minus the total wage bill (eq. 15). Id. (16) defines net corporate income $y_{f}^{n}$ as the income left after debt service. If net income is negative, the circuit closes only if firms borrow new money or manage to have their old loan rolled over. Any positive net income is saved (id. 22).

\section{Banks}

$$
\begin{aligned}
& C R=C R\left(r_{s}, \psi(C R)\right)=w_{k} \quad C R_{r}^{\prime}>0, C R_{\psi}^{\prime}<0, \psi^{\prime}>0 \\
& D=\sum_{h=i, j, f, b, F}\left(1-z_{h}\right) s_{h}
\end{aligned}
$$


Banks allow the circuit process to start. Firms negotiate with banks the amount and the terms of short-term bank loans to finance input acquisition and get production started. According to eq. (17) the supply of loans $C R$ to firm $f$ is positive in the short-tem interest rate $r_{S}$ and negative in the perceived risk of the borrower default, $\psi$. Other things being equal, the latter varies directly with the amount of loans supplied to the firm, on the assumption that the probability of borrower default increases as the credit extended overruns the firm's collateralized assets. ${ }^{6}$ Banks thus increase lending to the point where the marginal revenue from lending equals the marginal default risk. The amount lent determines the amount of inputs that firms can purchase in the factor market. Money is created as $f$ 's bank account is credited with the loan amount. Following $f$ 's spending on inputs, new incomes and savings are generated. Agents may hold a share of savings in band deposits D (id. 18). For simplicity, it is assumed that no cash circulates in the economy and that payments are made through deposit transfers from (and to) bank accounts. Deposits are used as means of payment and as precautionary savings. It is also assumed that banks do not run production and interest costs on deposits. Bank income is given by the interest earned on credit actually repaid (in eq. $19, \psi^{-}$is the ex-post rate of default on debt) and is fully saved (id. 22).

\section{Investment financial institutions}

$$
\begin{aligned}
& L F^{d}=I^{d} \\
& L F^{s}=\sum_{h=i, j, f, b, F} z_{h} s_{h} \leq S \\
& S=\sum_{j=i, k} s_{j}+y_{f}^{n}+y_{b}+y_{F} \\
& L F^{s}=L F^{s}\left(r_{L}^{-}, r_{L}^{-*}\right) \\
& r_{L}^{-}=r_{L}+q \\
& r_{L}^{-*}=\left[r_{L}^{-}-\phi\left(r_{L}^{-}\right)\right]_{\max } \\
& y_{F}=q L F \\
& L F=I=\min \left[L F^{s}, L F^{d}\right]
\end{aligned}
$$

Investment financial institutions play a central role in the model as they enable the circuit process to close. Conversely, their inability to manage costs associated with limited knowledge and incomplete trust is conducive to circuit breakdowns.

The demand for capital good $I$ from the investing companies is funded with long-term loans and/or equity funds, $L F$ (eq. 20), generated by aggregate saving as indicated in relations (21) and (22), and channeled to investing companies through financial investment institutions. Investment financial institutions adjust long-term fund supply based on gross rate of return $r_{L}^{-}$ adjusted by a risk-factor increasing in $r_{L}^{-}$(eqs. 23 and 24). Funds are supplied until $r_{L}^{-}$reaches its maximum and are rationed thereof (eqs. 23-25) in a Stiglitz-Weiss fashion. Note the difference between the supply schedule of short-term loans discussed above and that of long-term loans. The latter is more fundamentally commensurate to the fund-user's perceived capacity to earn a future stream of returns sufficient to recover the cost of funds. An increase in such cost may thus prejudge the fund-user's solvency. Relation (21) indicates that long-term funds to the economy 
may fall short of aggregate saving (see also section II.1.2); this can result either from investment financial institutions rationing the supply of funds, or from them being rationed in the capital market by fund-savers. Investment financial institutions charge a competitive unit fee $q$ on the funds supplied (eq. 24), reflecting their value added for production of information and trust; they are assumed to be cost-free and earn income $y_{F}$ (eq. 26), which they fully save (id. 22). ${ }^{7}$ The supply schedule of financial investment institutions bears important incentive-related implications that will be dealt with in part $\mathrm{II}^{8}{ }^{8}$ The investment actually funded (in Davidson's sense) is the minimum between the supply and demand of long-term funds (eq. 27). General equilibrium requires that

$$
c^{s}+I^{s}=\sum_{j=i, k} c_{j}+I^{d}=\sum_{h=i, k, f, b, F} y_{h}
$$

In equilibrium, the investing companies raise enough funds in the capital market to settle their contract obligations with the capital good producers, and consumption good producers sell all their output in the market. The circuit closes as producers use the proceeds from sales to clear their debts with the banks. In the CTF model proposed, microeconomic variables $v, r_{L}$, $\psi, \psi^{-}, \phi$ and $q$ are crucial in determining the level of real aggregate production at which equilibrium is attained, and the efficiency of resource allocation.

\section{Chart 1. The circuit}

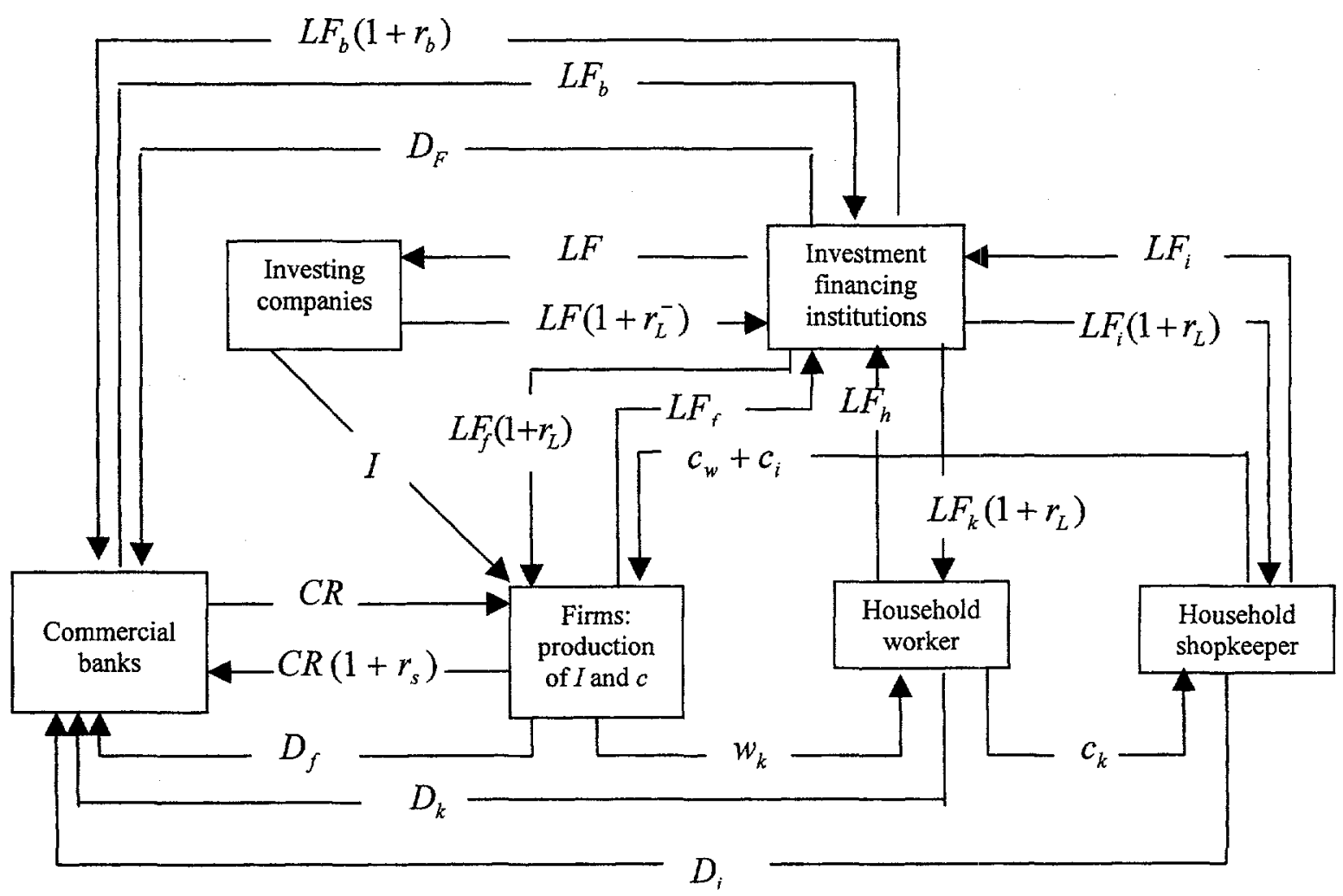


Although the model's equations do not bear explicit time references, a logical sequence underlies the circuit process (see Chart 1). In Appendix I, the equations are reordered according to CTF logical sequence. In reality, multiple circuits overlap at all times as new credit is created, new production is carried out, and banks retire debt on old production.

\section{I.1.2 Structural implications of CTF}

Circuit theory of finance (CTF) bears important implications in terms of financial market structure, microeconomic imbalances, and the role of saving for economic growth.

Financial market structure. The model marks the different role played in the circuit by the credit market on one side, where liquidity is created to finance production, and by the financial market on the other, where the existing liquidity accumulated by savers is allocated to investments. This, in turn, implies a distinct role for commercial banks and investment financial institutions whereby: a) commercial banks operate upstream in the circuit process, provide new liquidity to finance production in the form of own liabilities, and act within a short-term horizon; and b) investment financial institutions operate downhill the process and act as capital market intermediaries with longer-term horizons, collecting liquidity from savers with long positions and allocating it to investors with short positions. They may as well invest their own money directly. Their function enables capital good producers to repay their short-term debt to commercial banks and close the circuit. ${ }^{9}$ Also, by directing funds to investing companies, investment financial institutions are important instruments of corporate governance. As their long-term income eventually derives from their earned reputation as fund allocators, their long-term interest lies in selecting best investment opportunities and in ensuring good use of funds by investing companies.

CTF shows that banks and capital market institutions perform complementary functions. Depending on the structure of financial sectors and the stage of economic development, these functions might be carried out either by separate institutions, or jointly by more universal ones. This, however, should not hide the distinct nature and role that each function performs along the circuit. Also, complementarity implies that even in countries where financial systems are centered on capital markets, safe and efficient commercial banking functions (notably, related to the provision of liquidity and transaction services) remain crucial for the efficient and stable functioning of capital markets. The importance of complementarity between banks and capital market institutions is confirmed by empirical evidence (see section I.2). Also important is complementarity of the information produced in performing each function: through account relationships, commercial banks build up specialized knowledge of the enterprises' day-to-day business and liquidity, and of short-term developments of demand and supply in the specific sectors and markets where enterprises operate. Investment financial institutions, on the other hand, develop greater knowledge of longer-term business prospects and potential of investing companies, macroeconomic economic developments and financial market trends, change in fundamentals that may affect the long-term profitability of their clients.

Finally, a critical implication of the functional distinction and complementarity singled out by CTF is that those financial systems where functions are segmented are more prone to circuit malfunctioning and instability (see below). Segmentation in the financial structure, or outright lack of financial intermediaries in relevant segments of the capital market, are particularly relevant for countries at early stages of development. They may create severe discontinuities in 
the circuit and constrain economic growth. Such discontinuities limit the mobility of saving, lead to inadequate investment funding and/or to inappropriate maturity structure of investment funding; in period of economic booms, and especially in the aftermath of economic and financial liberalization, they likely lead to excessive lending to capital good production and to use of shortterm lending for investment funding. Also, discontinuities may cause poor information transmission across market segments and, most of all, they may set wrong incentives to the efficient use of information from individual financial institutions, delaying their response to market developments and eventually leading to macroeconomic imbalances, as discussed next.

Microeconomic imbalances. CTF and the microeconomic interactions built in the model produce some interesting and unconventional theoretical results. In particular, the following propositions can be shown to hold in a closed economy (see Appendix II):

Proposition 1. For any given level of aggregate investment, changes in individual or sector savings do not affect the volume of aggregate saving, although they affect the economy's saving ratio.

Proposition 2. Changes in aggregate saving can only result from changes in the level of aggregate investment

Proposition 3. Changes in the interest rate do not affect aggregate saving, although they may alter its composition.

Importantly, the model shows that that the availability of aggregate saving per se can never be an issue, as investment always generates an equal amount of saving, whatever the saving behavior of agents. However, the model points to the possibility that savings might not fully fund investments (in Davidson's sense), essentially impeding the closure of the circuit (circuit breakdowns). This corresponds to relation (18) taking the inequality sign. As mentioned earlier, the inequality may be explained by risk considerations. High liquidity preference due to generalized market uncertainty may prevent the maturity matching of supply and demand of funds, as households prefer to hold a lower share of savings in long-term assets, thus rationing supply of long-term funds to investment financial institutions. In an open economy, the same effect holds if funds flee abroad as a result of increasing uncertainty.Also, channeling savings in tangible real assets - as it happens in least developed countries, or in periods of high monetary instability - produces circuit breakdowns by preventing funds from flowing back into the circuit.

Circuit breakdowns may occur when agents hold part of their savings in bank deposits and banks do not correspondingly extend new credits (or roll-over old credits) to indebted firms: as money flow to the banks and no money is created, liquidity is withdrawn from the circuit and firms are prevented from re-possessing the money spent on inputs, thus defaulting on debt repayment. This implies that, with deposits outstanding in the agent portfolios, a stable circuit process may be consistent with a positive net short-term debt position of the corporate sector visà-vis the banking system, only if banks refinance indebted firms by the amount needed and for as long as necessary (Graziani, 1988). CTF can thus provide a mechanism whereby an increase in the agents' liquidity preference showing up in a larger demand for bank deposits may create circuit breakdowns.

At a more microeconomic level, inaccessible information on a fund-user or his low creditworthiness may discourage investment funding. Similarly, the risk premium on individual fund-users, or the level of transaction costs to deal with them, may require so high a return on funds supplied that would make the ex-post return more uncertain. Also, moral hazard and adverse selection problems likely rise with the interest rate charged and make the investment riskier. Under these circumstances, investment financial institutions may ration their supply of 
funds and make savings unavailable to fund-users (even though these aggregate saving equals investment). ${ }^{10}$

The integral nature of the circuit is such that misbehavior from agents upstream in the circuit may disturb the circuit functioning downhill he process. Also, in a repeated-game context, circuit closure (or unclosure) may impact upon subsequent circuit rounds by affecting agents' budget constraints and expectations. In terms of the above model, a closure failure would feed back on the banks' short-term loan supply schedule and lead to credit rationing and a lower activity, as well as to lower expected investment and capital good production. Under protracted circuit breakdowns, macroeconomic imbalances may eventually arise.

Circuit breakdowns may be caused by structural impediments to capital demand and supply matching, or as a result of inefficiencies in the information flow between banks and investment financial institutions. Circuit breakdowns more likely occur where investment financing and funding are segmented and carried out by separate institutions, specialized in different maturity habitats and operating under limited information sharing and idiosyncratic incentives. In such circumstances, lending decisions of short-term lenders, who are not concerned with long-term risks, might become inconsistent with conditions prevailing in longer-term maturity habitats, leading to overfinancing of capital good production. Figure 1 shows financial investors rationing investing companies at the point of maximum risk-adjusted gross rate of return, $r_{L}^{-*}$, and thus determining a funding gap equal to $S-L F\left(r_{L}^{-*}, r_{L}^{-*}\right)$.

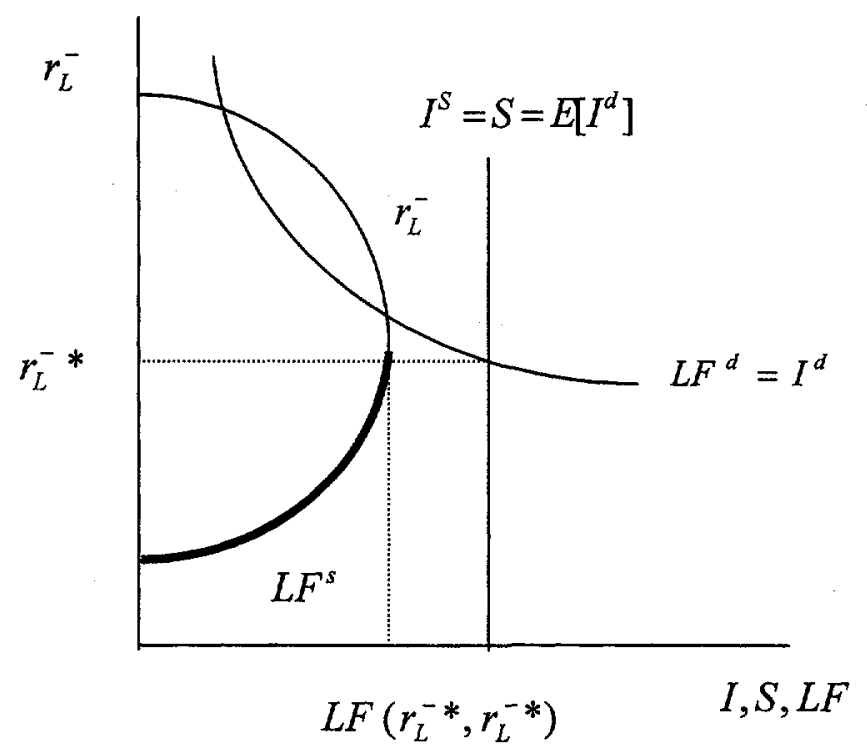

Figure 1. Investment funding in CTF

Saving, investment and growth. In a closed-economy, the interactions of the agents along the circuit prevent changes in individual saving decisions from affecting aggregate saving, and are such that no saving shortages can ever occur for any given level of aggregate investment. ${ }^{11}$ Why 
does saving matter, then? CTF introduces a new perspective from which to look at the role of saving for economic growth. Bossone (1998a) shows that for a condition for equilibrium growth is

$$
\sigma^{*}=b i /[1+(1+i) d \beta A]
$$

where $\sigma$ is the economy's saving ratio, $b$ is the accelerator, $d \beta$ is the change in capital good production to output ratio, $i$ investment demand growth, and $A$ is the output-capital ratio (see Appendix III). Conditions (29) requires that the saving ratio vary directly with demand factors $b$ and $i$, and inversely with supply factors $d \beta$ and $A$ (Figure 2).

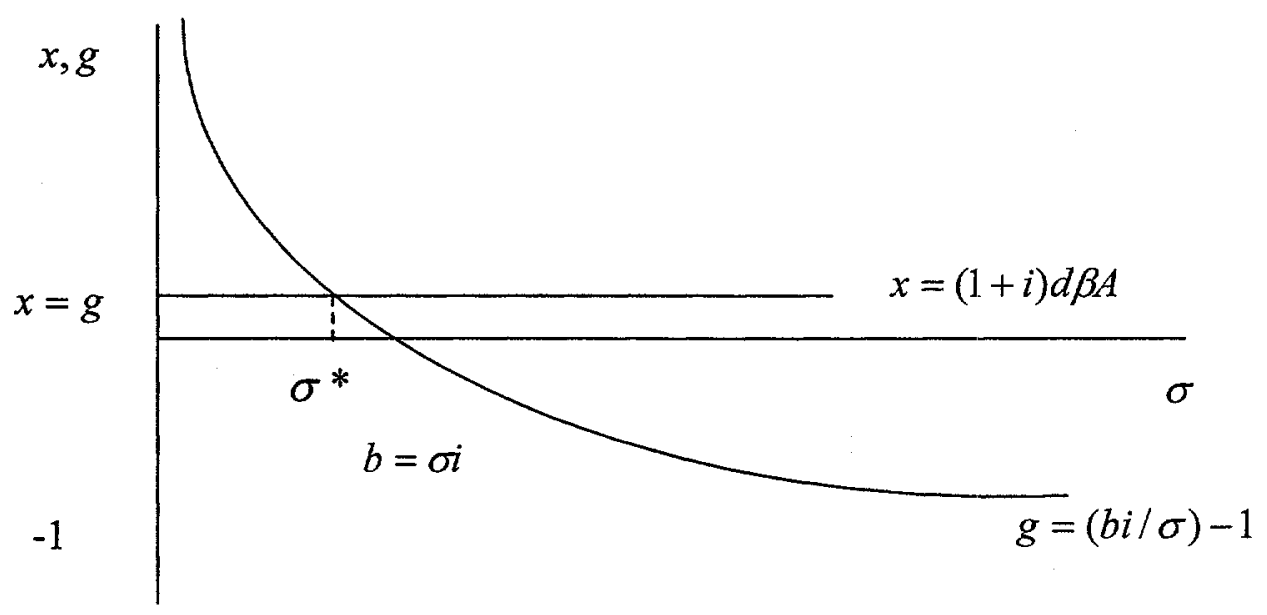

Figure 2. Saving and growth in CTF

It clarifies the role of saving in economic growth: to the extent that capital good production is financed by short-term lending and that saving accumulates residually as production is financed, saving cannot constraint investment ${ }^{12}$; however, a low (high) average propensity to save may generate inflationary (deflationary) pressures along the circuit. Macroeconomic policy should thus steer the average saving ratio to the level where the economy achieves macroeconomic dynamic balance. The role of saving for growth in CTF differs from its role in neoclassical growth theory (Box 2). 


\section{Box 2. CTF and Neoclassical growth theory}

Neoclassical growth theory (NGT) holds that higher rates of saving are necessary for the economy to shift to higher growth rate paths. In traditional NGT (Solow, 1956), the saving ratio determines the level of per capita output, although it does not affect the rate of output growth; in endogenous NGT (Solow 1994), the rate of saving determines the output growth rate. The primacy of saving in NGT rests on the following basic assumptions: 1) at any time, output is given at its full employment level; 2) the act of saving always precedes that of investment, both logically and temporally; 3) in a closed economy, all saving is invested; 4) no increase in investment can take place without a corresponding increase in saving necessary to finance it; and 5) if ex-ante savings diverge from ex-ante investments, the rate of interest adjusts until the two equal. Unlike in CTF, in NGT the agents' interactions do not interfere with the process of saving accumulation since output is determined by the intensity of factors use and is not affected by demand: an increase in the saving ratio does not lower output and translates directly into larger aggregate saving, thus freeing up resources for extra investment. In fact, only two (alternative) assumptions can make this result possible: a) saving and investment decisions are taken simultaneously by the same agents ("representative agent" models fall into this first assumption category); 2) saving and investment decisions are taken by different agents but they are fully coordinated through perfectly competitive and complete markets, so that if some agents decide to decrease their savings, their decisions are fully matched by others' decisions to decrease investments (this assumption is adopted by Solow, 1994, sect. 2). As CTF shows, short of these assumptions and with agent interactions, any temporal separation of saving and investment causes the former to adjust to (and to always equal) the latter. In CTF, aggregate saving is residual and the saving ratio only affects the macroeconomic balance. Gordon (1995) found supporting evidence to this reverse saving-investment relationship.

\section{I.1.3 Efficiency and stability implications of CTF: the role of incentives ${ }^{13}$}

Depending on the economy's institutional setting (including the role of the state, restraints on market competition, and restrictions on capital movements), the circuit process can produce different efficiency-stability configurations, with related implications for the economy's incentive structure. Consider the following - highly stylized - representations.

Early in the process of industrialization, as in XVIII-century Europe, the circuit process is dominated by manufacturing firms and commercial banks. Family-owned firms specialize in profit-oriented production and commercialization of commodities. Capital accumulation is mostly financed by owners through own resources, and bank credit is used to finance production and inventories. To ease commodity trade, firms extend private credit to each other, as well as to buyers, often guaranteed by banks. A monetary system replaces barter as final payments are no longer made through exchange of real commodities, but via transfers of third-party commitments to honor payers' debt obligations, and as such commitments are accepted as means of payment in subsequent transactions. As firms negotiate with their bankers the terms and conditions of credit access, they and the bankers determine the total level of resource employment for the given technology of production. Since firms internally finance capital goods used in production, they as a group - determine the share of total resources to be allocated to consumption and investment. To the extent that labor market negotiations set the nominal wage and that trading involves only 
commodities already produced, firms (as a group) also determine the volume of output that they would re-appropriate at the end of the circuit round (see Appendix VI). Workers' saving decisions that turn out to be inconsistent with firms' production plans induce commodity price adjustments to the point where enough funds flow back to them firms and enable them to service their debt. The short-term interest rate on commercial bank lending determines the real resource transfer from firms to banks. The circuit underlying early industrial economies is rudimentary and relatively stable overall. Accumulation is constrained by lack of organized finance for long-term investment and depends almost exclusively on capital owners' personal wealth.

The structure of the circuit process evolves toward financial industrialism as demand for capital equipment intensifies, larger financial resources need to be mobilized beyond the means of wealthy owners, new firms specialize in capital good production, and banks use their earned reputational capital to develop investment banking functions in financial intermediation. Capitalism took on this route in Europe and America of late 1800s-early 1900s. With capital markets in their infancy and relatively few (as well as unsophisticated and not well informed) large investors, a seal of approval from investment banks ensure that firms enjoy unimpeded access to capital at affordable terms. Banks provide investing companies with "patient money" that can afford them to take a long view. ${ }^{14}$ They make sustained investment possible, and their reputation mobilizes funds needed to make the circuit operate smoothly. The other face of the coin is that exclusive bank-client relationships develop with a common interest to protect firms' cash-flow at any cost, thus leading to market opaqueness (by limiting disclosures of crucial information), and to restrictions to competition through industry coalitions, cronyism and monopolies. As a result, incentives to efficiency, innovation and new industries may weaken in the long term.

To a large extent, the expanding role of the state in the economy (as experienced in the industrial countries after the 1930 s, and especially in the second post-world war period) replaces investment banking at the core of the financial circuit, not only by directly absorbing savings but by intervening in the allocation process through financial repression, directed lending, lending of public money, and direct ownership of financial institutions. With the state as a large financial intermediary, fund-savers need to be less concerned with the reputation of private-sector institutions, as they increasingly revert funds to state-owned or controlled institutions on the basis of the implicit guarantee of (perceived) unlimited solvency of the public sector. Also, the large share of public spending on aggregate output stabilizes the flow of funds that firms need to reappropriate at the end of the circuit process. In terms of the CTF model discussed above, the large role of the state in the financial sector would be reflected in a flatter long-term supply schedule, with equilibrium at a higher level of investment, possibly beyond the point of equality between interest rate and capital marginal efficiency. In fact, the cost of funds bears no relation to borrower risk and to the value added obtained from production of information and trust. If adopted, rationing would be decided centrally by the government, based on macroeconomic policy objectives rather than on risk considerations. State-controlled finance ensures greater stability of fund supply, but also causes inefficient selection of investing companies, firms' higher moral hazard and weaker incentives to good investment and competitive production. The state role as financial intermediary essentially severs the investors' decision to invest from their incentive to earn a profit. The incentive effect at the economy's level is that large investment results in long-term growth stagnation and a highly leveraged corporate sector.

The response to this state of affair involves a substantial correction of the economy's incentive structure. This can be accomplished by repositioning the private sector at the core of financial intermediation, in particular through establishment of financial institutions specialized in investment financing. This route has been followed to date in the industrialized countries and 
in an increasing number of emerging economies. Investment financial institutions, such as institutional investors, manage funds on behalf of small savers (households) and on the basis of household risk-return preferences. Their reputation builds on their ability to satisfy those preferences better than their competitors, and their market behavior is to reflect the household objective functions as closely as possible. In line with CTF predictions, this implies that risk aversion as well as sensitivity to risk and uncertainty tend to be greater than in more centralized financial regimes. As a result, no exclusive lender-borrower relationship can survive in a competitive financial regime as financial institutions need to retain the flexibility needed to rapidly adjust to changes in market conditions. Nor information advantages can ensure permanent extra-profits as efficient signal transmission competes those advantages away. Thus, fund-users are subject to stronger market discipline since funds can be more easily withdrawn from enterprises perceived to be riskier. This motivates corporate managers to select better investments and pursue sounder strategy and administration. On the other hand, markets become subject to higher volatility due to sudden changes in financing decisions driven by shifts in risk perception. Thus, while resource allocation is more efficient than in alternative regimes, the circuit process is vulnerable to higher breakdown risks. Greater uncertainty can more easily result in credit restrictions to production and weaker incentives to long-term investment funding.

Emerging economies are moving rapidly toward market-led financial systems with an increasing presence of (domestic and foreign) institutional investors. As their financial relations become more and more dominated by profit-driven individual preferences, incentives may be necessary to induce agents to pursue prudent and honest behavior, and support the overall stability of the circuit process. In particular, with the growing role of market forces, the public sector should pursue take actions to assist markets to achieve better efficiency-stability tradeoffs. These issues will be taken up in part $\Pi$.

\section{I.1.4 Theoretical and methodological features of CTF}

From the preceding arguments, the main methodological features of CTF can be summarized as follows:

- CTF explains finance as the institutional complex aimed to minimize transaction costs (associated with limited information and incomplete trust) in the exchange of promised claims on real resources taking place in a sequential economy

- CTF emphasizes the complementarity between commercial banking and investment financial functions in a sequential economy

- CTF shows that in a market economy investment funding problems may cause circuit breakdowns even though aggregate saving always equals investment

- CTF reverses the neocalssical saving-causality nexus, and shows that investment determines saving and that saving can never contrain investment

- CTF allows for both neokeynesian-type disequilibria and postkeynesian-type underemployment equilibria to hold in the model as a result of rational individual choices, the former due to risk-related credit and equity rationing, and the latter to high liquidity preference driven by uncertainty. In particular, CTF explains production overfinancing, excessive risk taking by investors, and changes in investment funding decisions in terms of individual rational responses to economic incentives

- By integrating money, credit and finance in a sequential process, CTF permits to identify discontinuities and weaknesses along the circuit structure, and to assess their impact. It also indicates how shocks can get transmitted within a circuit round and through sequential circuit rounds 
- by linking the macroeconomic and microeconomic dimensions of finance and by involving agents' interactions, CTF overcomes the analytical shortcomings of "representative agent" models of intertemporal resource allocation, as well as those of the pure macroeconomic approach of monetary circuit theory. It creates a greater scope for studying the role of marketcompatible incentives in reconciling microeconomic behavior and macroeconomic objectives

- CTF allows for comparative analyses of incentive structures underlying the circuit process under different institutional settings and in different stages of economic development.

\section{I.2 Finance, growth, and stability: brief conceptualization and recent evidence}

CTF clarifies the role of the financial system in the functioning of a monetary market economy of production. At the start of the circuit process, the financial system supports real production by creating and advancing liquidity to producers; along the circuit, the financial system governs the supply and demand of funds and, at the end of the process, it determines the condition for the closure of the circuit. As discussed, the conditions under which one circuit round succeeds or fails to close affect the way in which new circuit rounds start and unfold. With aggregate saving accumulating residually as production is financed, investments are viable only if they can be funded on terms consistent with their required profitability. The role of finance is thus to ensure that all profitable investments get adequate funding at the lowest possible costs.

The microeconomic nature of such role emerges from considering that investments extend the time and risk dimensions of the exchange process, calling on agents to trade current real resource claims in exchange for (uncertain) promises to receive back real resource claims at some given point in future (augmented by some appropriate margin). In a decentralized-decision context, with a multitude of heterogeneous agents operating under limited knowledge and incomplete trust, the financial system provides the complex of institutions, contracts, regulations, monitoring and enforcement mechanisms, and exchange procedures that make the terms of promises acceptable, affordable, and reliable to participants. Clearly, the higher the acceptability, affordability, and reliability of financial promises, the wider can be the time-horizon underlying agent decisions and the grater the circuit stability.

Financial institutions collect, process, and disseminate information. Building on their own reputations, they provide confidence in markets where individual participants cannot easily provide a basis for complete trust. To earn and maintain reputation they must see to it that funds are allocated to best investment opportunities and that, once allocated, funds are used appropriately by investing companies. Financial institutions also offer the benefits of economies of scale and specialization by agglomerating capital and information that would otherwise be widely dispersed. By virtue of their specialization and scale economies, they operate as delegated monitors on behalf of investors.

Thus, the core role of the financial system, as framed in CTF, is to provide the microeconomic setting to ensure that $I^{s}=I^{d}$ and $L F^{s}=S$, at the point where $\rho=r_{L}^{-}$. This allows the economy to optimize capital efficiency and the circuit to close under conditions of macroeconomic equilibrium. ${ }^{15}$ The effectiveness of the microeconomic setting rests on the ability of the financial institutions to overcome the information and trust scarcities of the economy, and 
to produce the correct incentives to reconcile choices from anonymous investors and savers, as well as from different firms operating on the two sides of the capital good market.

Thus: In a market economy with limited information and incomplete trust, an efficient and stable financial system fundamentally complements the price mechanism in providing signals to reconcile the opening and closure phases of the circuit process, ensure the smooth sequence of circuit rounds, and allow the circuit process to grow steadily. With finance increasingly decentralized and financial decisions reflecting the objective and reaction functions of small, risk-averse, and interacting individuals, the overall stability and efficiency of the circuit process can best be achieved through incentives aimed to induce profit-seeking agents to internalize prudence and honesty within their decision plans.

Finance is therefore crucial for developing economies that have embraced, or seek to embrace, the market. Part II will argue that financial sector reforms based on incentives and incentive-compatible institutions can help achieve the maximum developmental potential of finance.

Recent research following the seminal work of King and Levine (1993) confirms that strong links exist between growth and finance and that a better developed financial sector precedes faster growth. ${ }^{16}$ Analyses show statistically significant links between both the extent to which commercial banks allocate credit and the tendency of financial systems to lend to private firms, on the one hand, and productivity growth on the other.

More credit extended to private firms likely coincides with banks performing more effectively their credit assessment, monitoring, and corporate governance functions, as well as doing a better job of providing efficient payments systems, than would be the case if governments and government-owned enterprises were the banks' main clients. Although it is possible that more developed economies lead to better financial systems, recent evidence finds that economies with deeper financial systems in 1960 saw faster growth in the following 30 years. This suggests that the effect of financial sector development on economic growth is significant. ${ }^{17}$

Capital markets, too, have a positive effect on growth. Of 38 countries with the requisite stock market data, those with highly liquid equity markets in 1976 saw more rapid growth between then and 1990. And those with more liquid stock markets and more developed banking systems experienced the most rapid growth rates. This complementarity of banking and stock markets, which appears throughout most stages of development, likely arises because both debt and equity finance induce better accounting, auditing, and formation of a cadre of trained finance professionals. More important, as suggested by $\mathrm{CTF}$, complementarity arises because efficient equity markets need to rely on efficient banking for the provision of liquidity, payment, and securities management services (OECD, 1993). It is only as countries reach the per capita income levels of OECD countries that further stock market development seems to induce a decline in firms' debt-equity ratios, as many of those services are progressively produced by non-bank financial institutions.

Convincing evidence of the relationship between finance and development also emerges from a look at how financial resources are allocated among firms before and after financial reforms. Schiantarelli et. al. (1994) found that, following financial reforms in Ecuador and Indonesia in the $1980 \mathrm{~s}$, there was an increased tendency for finance to be allocated to more efficient firms than before the reforms: with less intervention in credit allocation and pricing, intermediaries were more likely to allocate capital where it would be best used, thereby raising economic growth. ${ }^{18}$ 
Moreover, a cross-country study with firm level data confirms that finance matters for growth and highlights specific policy changes, such as improvements in the legal system, which foster development (Demirguc-Kunt and Maksimovic, 1996). Cross-country research using both firm level and aggregate data show that improvements in legal systems foster growth (Levine $e t$ al., 1998). Conversely, a financial system with structural impediments, or subject to instability, can greatly disturb the economy's orderly evolution. Caprio and Klingebiel (1996a) show the substantial fiscal costs and the costs of foregone output associated with banking crises in several countries over a twenty-year period since the mid-seventies.

Times of crisis are usually occasions for recognizing past mistakes; the currency and financial crisis of East Asia has given great impulse to the effort to revisit fundamental financial sector policy issues, ever since it became clear that the failures experienced in the region lay with the weaknesses of its financial systems. The current policy debate draws heavily on lessons learnt from East Asia's crisis. Unlike the Latin American debt crisis in the 1980s, the problems in East Asia revolve around private sector indebtedness transactions and, in particular, around the shortterm nature of private debt and the large portfolio outflows. ${ }^{19}$ Weak financial risk-management in financial institutions and high corporate debt were major sources of instability. These created the conditions for serious financial imbalances. Lack of information also played an important part, as markets realized that many firms were much weaker than they had thought. Similarly, as the crisis spread, lack of information may have led lenders to a generalized withdrawal of funds from the economies, without discriminating between good and bad firms.

Also, as CTF predicts, segmentations between the short- and the long-term ends of the capital markets may have been a cause of the excessive growth in short-term lending to the region. At a time of over-heating and over-optimistic expectations, short-term lenders - typically less concerned with the long-term risks of the investment financed, and in some cases lending under the perception of implicit government guarantees on losses, increased their exposures to domestic enterprises, even though signs may have growing of an unsustainable pace of capital accumulation. As a result, the production of capital goods exceeded its sustainable demand. To the extent that much domestic borrowing was funded by foreign creditors, it is fair to conclude that not only domestic institutions but international markets as well failed to perceive the increasing East Asian risk.

Thus, market failures weakened East Asia's financial systems, causing excessive risk and resource misallocations. Governments made things worse: unsustainable exchange rate pegs have distorted the incentives in a way that led to the buildup of vulnerability, especially in the form of rising short-term dollar-denominated debt. East Asian financial systems also suffered from inadequate financial regulation and from too rapid liberalization. Domestic and external financial liberalization increased competition for creditworthy borrowers, which reduced the franchise value of banks and induced them to pursue risky investment strategies. In some cases (Korea and Thailand), rapidly growing non-bank financial institutions were allowed to operate without adequate monitoring. Also the close link between banks, corporates and government and the lack of a clear demarcation line between their different responsibility and interests (such as in Indonesia, Korea, and Thailand) caused severe deficiencies in allocation and risk-taking decisions.

The lingering effects of past policies that dealt with financial distress magnified the impact of these weaknesses. Several countries - Thailand in 1983-87, Malaysia in 1985-88, and Indonesia in 1994 - had experienced financial crises that were resolved through partial or full public bailouts. These bailouts reinforced the perception of an implicit government guarantee on deposits, or even other bank liabilities, thus damaging market discipline. In some cases, 
management of restructured financial institutions was not changed, which did nothing to improve incentives for prudent behavior.

\section{Financial sector reforms in emerging economies ${ }^{20}$}

Circuit theory of finance provides useful insights to draw a consistent strategy orientation for financial sector reforms in emerging economies. By combining the macroeconomic and microeconomic dimensions of finance in a methodological setup open to institutional change, CTF offers a framework to design financial sector policies for countries in transition from financial repression to market-based finance. In particular, by portraying market-based finance as an intertemporal circuit process whose successful opening and closure phases depend on its power to reconcile decentralized, CTF helps identify a number of core reform policy areas where incentives can be improved to lead financial institutions to better perform their reconciliation function. Such core areas range, just to cite a few examples, from the progressive elimination of discontinuities in information and money flows along the circuit, to the provision of trust in support of promises underlying financial transactions across the circuit timeframe, to the selection of agents with higher reputational capital both to increase the circuit's robustness and to broaden its time-horizon basis, to the inclusion in the circuit of agents otherwise barred from it by unaffordable transaction costs due to structural impediments. To the extent that incentives are crucial in the success of finance to reconcile decentralized decisions, the lead interest of part II of this paper is to identify incentive-based policies that can align individual profit-oriented objectives with the social goal of financial stability.

\section{II.1 CTF and incentive-based financial sector reforms}

As discussed in part I, the financial sector provides the information and trust necessary for a market economy to accomplish its circuit functioning smoothly, as well as to expand the circuit in a sustained and sustainable way. The links explored under CTF between the macroeconomic and microeconomic dimensions of finance suggest that reforms aimed to strengthen the financial sector in a market economy should seek to induce market players to reduce transaction costs by generating and mobilizing information and trust.

This section makes a case for designing incentive-based financial sector reforms, that is, reforms based on incentive mechanisms, rules and institutions aimed to align individual economic motives with the public objective of financial stability. By allowing prudent and honest behavior to be appropriately rewarded, financial institutions can be motivated to internalize prudent and honest actions within their set of economically rational choices. Also, if financial institutions operate in a context where individual misconduct hurts the others while good conduct lowers transaction costs for all, they all have an incentive to undertake self-policing through which they monitor each other's behavior and sanction misbehavior. ${ }^{21}$

The economic literature offers plenty of examples and a sound body of theory in support of the argument that, in an environment with limited information and incomplete trust, pricing 
honesty and prudence can be quite effective to reduce opportunistic and risky behaviors from self-interested and rational individuals (Benson, 1994; Klein, 1997a).

Pricing honesty and prudence links the agent's stream of future profits from her business to her past business conduct: as the agent proves dishonest or imprudent, her counterparties withdraw from dealing with her, causing her to lose all future profits. Thus, pricing honesty and prudence leads the agent to invest in reputational capital, that is, the value of her commitment not to breach (implicit or explicit) contracts, or to take risks that might endanger her compliance with contract obligations. ${ }^{22}$ If the agent breaks the contracts, her reputational capital may be damaged or destroyed. In equilibrium, if prudence and honesty are priced efficiently, the reputational capital of an agent must equal the present value of the stream of future profits, or franchise value, of her business.

The concept of reputational capital is meaningful in repeated-game contexts. The longer the agent's time horizon, the higher the chance that her franchise exceeds short-term gains from cheating. As noted in discussing the CTF model in part I, this point relates to the behavior of private-sector financial institutions, and bears implications for the stability and integrity of the circuit process in a market economy. Stability relies on the long-term commitment of financial institutions to prudent and honest behavior. It is thus important that incentives to build a strong reputational capital are in place. From the CTF features discussed in part I, three areas emerge where incentives to prudence and honesty can be devised: competition, regulation and supervision, and information.

First: competition. The overall competitive environment influences the incentive for institutions to develop enduring franchise value. Policy has an important role in influencing the degree and nature of competition both within the banking system and between banks and investment financial institutions. Promotion of competition has to go hand in hand with the need for financial institutions to build reputational capital. A strong reputational capital mitigates short-termism in institutions financing production upstream in the circuit, and motivates investment financial institutions downhill the circuit to improve their capability to support sound long-term investment. This helps to reconcile starting and closing phases of each circuit round (intra-circuit stability), as well as to reduce shocks from one round to the next (inter-circuit stability). As CTF indicates, a well balanced financial structure is necessary for competition to be consistent with stability: incentives should be used to attract to the market the range and types of institutions apt to fill the whole spectrum of (sectoral and maturity) segments of the circuit, thus eliminating circuit discontinuities. In particular, promotion of competition should take into account the complementarity between banks and investment financial institutions emphasized by CTF. This implies that incentives to non-bank financial institutions should be considered only provided that basic banking services and infrastructures are in place, or under development. Finally, as economic decentralization intensifies, the role of finance as a bridge of trust needs to be strengthened so as to reduce transaction costs.

Second: prudential regulation and supervision. The microeconomics of CTF discussed in part I suggests that, as aggregate saving is in all cases equal to investment - once agents' interactions are duly factored in - competing for savings in the capital market is less a question of bidding higher prices to induce more production of a "scarce" resource, and more a matter of bridging the gap of trust that separates anonymous savers from fund-users. ${ }^{2.3}$ Access rules to markets and the incentive structure built in regulations should thus ensure that participants aim at accumulating and maintaining strong reputational capital. Also, bridging trust gaps involves externalities to the extent that dishonest and imprudent action from one market participant may damage the reputational capital of others, and that sound financial infrastructures that strengthen 
trust and prudence increase the return to all participants. Thus, producing and maintaining financial infrastructures require cooperation both among market participants at the industry level, and between the private and public sectors. In particular, externalities in production of trust and prudence call for private-sector self-policing arrangements as generating incentives to higher efficiency and stability.

Third: information. The incentives for acquiring, exploiting, and disseminating information are central to the effective functioning of a financial circuit process. On the one hand, the emergence of a market for financial information is necessary to the integrity and stability of the circuit, especially as both decentralization of decisions and agent interdependence increase. In particular, CTF shows that efficient information provision is essential to reconcile choices from firms producing capital goods and investing companies, and choices from savers and fund-users. Reconciliation of such choices is vital both for intra-circuit and inter-circuit stability. Also, as CTF suggests, the stability of the circuit benefits from reducing segmentations that hamper efficient information flows and distort incentives to optimal intertemporal decisions. Banks must be able to assess the debt-repayment capacity of individual firms in deciding whether to refinance indebted firms at the end of the circuit round and under what conditions. They therefore stand to benefit significantly from factoring the long-term market potential of borrowing firms in their risk analysis. The higher their reputational capital, the stronger their incentive to lengthen the time horizon of their approach to risk management. Similarly, investment financial institutions would benefit from gaining knowledge associated with undertaking commercial banking relationships with fund-users, as these can provide relevant and timely information on changes in business conditions and market moods. Finally, personal and social linkages characteristic of the information structure in informal financial markets can be exploited to maximize complementarity between formal and informal finance, especially in countries at early stages of development with large shares of population beyond the reach of the formal financial circuit.

A financial sector reform strategy based on incentives is especially fitting where the need to economize on scarce resources is more pressing and the circuit is riddled with discontinuities in information and trust. In particular, four contentions justify the use of incentives for financial sector reforms in emerging economies:

- Incentives to prudence and honesty can protect the stability of the circuit by directing private sector forces unleashed by liberalization. Many developing countries have undertaken the transition from financial repression to market-based finance. The vulnerabilities of marketbased finance, discussed earlier, call for major institutional measures to prevent or minimize the likelihood of circuit breakdowns. Such vulnerabilities are most acute during liberalization, when private-sector agents are suddenly allowed to operate across a broader decisional space than under financial repression, with unpredictable shifts in structural parameters and very limited knowledge. Under these circumstances, incentives and incentive-compatible regulations are essential to induce agents to factor prudence and honesty in their action plans during and after reform.

- Emerging economies suffer from relatively scarce institutional resources in both the public and the private sector. In emerging economies the resources to be devoted to monitoring and enforcing rules and regulations are typically more scarce than in industrial countries. The necessary skilled human resources have a relatively higher opportunity cost (and the technologies available for control purposes are presumably less effective) than in industrial countries. Incentives to induce self-policing within the private sector would complement public sector's efforts to enforce rules and best practice standards. 
- If information and trust are scarce, there is a potential market for them. Where information is scarce and asymmetrically distributed, trust is incomplete and the incentives for opportunistic behaviors are significant, big profits can be extracted from providing reliable information and from building trust, provided that the returns can be appropriated by private agents. Where these activities are inhibited by problems of non convexities (externalities, internalities, or lack of coordination), the public sector can take action to induce the private sector to provide them, either cooperatively or in a competitive setting. The public sector may also engage directly in providing such services.

- Incentives may improve the efficiency-stability tradeoff. Unlike regulatory practices that seek to achieve stability by constraining business activities, incentive schemes that reward market participants for prudent and honest conduct improve the efficiency/stability tradeoff. In financial risk-management, rules can be designed that encourage private sector institutions to reduce risk exposures and economize on capital. ${ }^{24}$ Also, letting financial players choose their own risk control methods, under the threat that ex post miscalculation is penalized, gives them an incentive to improve their procedures to reduce errors that lead either to inefficient capital allocations or to insufficient risk coverage.

Emphasizing incentives is not to deny the importance of good rules, capable regulators/supervisors and strong enforcement measures; it is to suggest that the returns on investments to set up rules, supervisory institutions and enforcement mechanisms can be higher if market players have an incentive to align their own objectives with the social goal of financial stability. Public-sector investments in regulatory/supervisory systems could thus focus more on improving the quality (rather than on expanding the quantity) of the resources employed in regulatory/supervisory activities. An incentive-oriented regulatory/supervisory culture would also promote the osmosis of expertise between the public and the private sector. A large osmosis would also strengthen cooperation between regulators and regulatees.

Specific incentives-related policy issues and recommendations are discussed below.

\section{II.2 The elements of incentive-based financial sector reforms}

\section{II.2.1 Competition}

\section{Balancing competition with incentives to create franchise value}

Financial sector reform should induce financial institutions to invest in reputational capital. For financial institutions that are underdeveloped and were previously subject to state controls, measures to increase the value of bank franchises should be adopted. Some mild financial restraints may be needed to balance competition with incentives to induce domestic institutions to accumulate sufficient reputational capital; before being exposed to full financial liberalization.

CFT stresses the importance of banks as circuit-starters. To the extent that they often represent a large share of domestic finance, as is generally the case in developing economies, banks play a fundamental role also downhill the circuit as long-term financial investment institutions. It is therefore essential that financial sector reform starts by looking at the incentives for banks to invest in reputational capital. In cases where the franchise value of such institutions 
is low, rationalizing the financial industry is key. Authorities should aim to ensure an adequate number of private institutions with sufficient franchise to induce them to invest in reputational capital. This might involve mergers of exiting private institutions or privatization of state-owned financial institutions. Restructuring troubled institutions, too, offers opportunities to reposition them in the market and improve their profitability. Prospects for higher franchise value could also benefit from allowing financial institutions to operate across the maturity spectrum and in various market segments, provided that in each segment they would be supervised in a consolidated fashion.

Investment in infrastructure (including, notably, telecommunications) can significantly increase bank franchises by lowering transaction and operational costs. Real sector restructuring and investments would also have important positive indirect effects on franchise value, because of long-term productivity gains that would strengthen borrower net worth and broaden the domestic borrower base.

Some mild financial restraints on banking competition could also be a way to increase the franchise value of domestic institutions, especially in least developed countries and in those emerging from long periods of financial repression, or in deep financial crisis and restructuring their financial sector ${ }^{26}$ Moderate restraints such as time-bound market-based deposit rate ceilings and restrictions on market entry may have a large rent creation effect that would allow banks to raise profits during the initial phase of reform, giving them incentives to invest responsibly and to monitor the performance of borrowers carefully. Especially for banks that have operated for long periods under heavy financial repression with state-administered interest rates, the introduction of a market-linked ceiling on deposit rates could provide a gradual way toward full interest rate liberalization.

Hellmann et al. cit., show that the degree of restraints necessary to produce significant rents is such that would not generate large financial market price distortions. Also, to the extent that banks respond positively to the incentive by investing in reputational capital, the belowmarket interest rate on deposits would reflect their lower prospective riskiness, thus partly absorbing the distortion effect. Restraints should only apply in the early stages of reform and be phased out as banks, in the judgment of supervisors, accumulate sufficient reputational capital. In particular, supervision should ensure that rents are used for internal reorganization and restructuring, to improve the quality and safety of financial services, and to build a stronger capital base. Supervisors should also ensure that banks develop internal skills to evaluate risks in a competitive environment and adopt appropriate risk-management systems.

The ceiling on deposit rates should be set at a level generously above inflation, making allowance for some possible inflation variability, and slightly below its underlying market level. The ceiling could be anchored to an international interest rate on a comparable instrument (i.e., a money market rate) and adjusted for expected exchange rate movements of the domestic currency. Attempts from banks to circumvent the ceiling to attract new small depositors would have to be made known to the public and would thus be detectable by supervisors. ${ }^{23}$

Deposit rate controls should be accompanied by restrictions on market entry from other banks and non-bank financial institutions, as new entries might compete rents away. Temporary restrictions on market entry may be warranted to protect domestic financial institutions while they build reputational capital, but they should be balanced against the desirability of a financial sector that is open to domestic and foreign competition. Entry restrictions should eventually be replaced by strong and safe rules for market entry. These should include minimum requirements on capital, on organizational and operational structures, and on risk-management capacity. Strong criteria for 
evaluating whether bank owners and managers are "fit and proper" are crucial. Licensing requirements and standards, as well as their enforcement, should be transparent and based on objective criteria. They should be set at levels that imply serious initial commitments from owners and management wishing to enter the market; this would help the authorities select well motivated market entrants, induce potential entrants to evaluate correctly the prospects for sound business, and protect franchise value from entry of unfair and imprudent competitors.

Foreign participation in financial reorganization and restructuring, or de novo entry, should be explored, bearing in mind the need to weigh the potential gains against possible adverse consequences for domestic firms. Recent empirical evidence from a group of eighty industrial and developing countries (Claessens, Demirgüç-Kunt, and Huizinga, 1998) shows that a larger share of foreign bank ownership (and so greater competition) forces domestic banks to operate more efficiently through higher competition in national banking markets. Moreover, foreign entry can strengthen domestic financial markets by bringing in experience and technology, and by allowing greater diversification of individual portfolios. Some countries that had experienced large shocks - triggered in part by macro and micro distortions - reacted by quickly opening up to foreign financial firms and benefited, suggesting that internationalization can overcome the risks and upfront costs, including reduced franchise value, for domestic firms. In Mexico and Venezuela, foreign banks emerged as key players in recapitalization of banks; in Poland and Hungary foreign banks brought much needed know-how and capital; and in Argentina and New Zealand, foreign banks also brought fresh capital. In transition economies, cooperation between foreign and domestic banks has helped to improve capacity of local institutions.

Foreign financial institutions also have proven to be a source of stable funding in the face of adverse shocks. Following the Tequila crisis of 1994-95, the Argentine authorities allowed more foreign participation in their banking system, and by late 1997, nine of the top ten banks were majority foreign owned. In Mexico, after restricting bank privatization to domestic residents, authorities allowed sharp increases in foreign participation in banking following the peso crisis. In both countries, foreign banks supported the circuit by maintaining access to offshore funding, while domestic banks experienced strains. In some East Asian countries, as uncertainty increased, depositors moved to locally based foreign banks, thus retaining deposits for the local circuit.

\section{Creating a domestic investor base}

An important medium-term objective of financial sector reform is to endow the economy with a modern capital market and to encourage market entry by institutional investors. Completing the financial market structure reduces transaction costs and helps allocate savings to the best investment opportunities.

CFT emphasizes the importance of investment financial institutions for the economy's dynamic equilibrium and efficient intertemporal allocation of resources. Creating a stronger investor base amounts to strengthening the circuit by completing the financial market structure of the economy, thus eliminating discontinuities in the transmission of information and money flows, and enhancing the provision of trust to support larger and more articulated sets of financial promises. Better investment opportunities can be selected and sustained, more savings can be mobilized, demands and supplies of funds can be matched at lower transaction costs and with appropriate maturity, and the circuit process can operate more smoothly and on a growing scale. 
However, as banks play a predominant role, especially in the least developing countries, governments should move gradually. They should first concentrate scarce resources on establishing sound banking foundations, and plan to remove impediments to capital market development as a medium-term objective. The elements that will contribute to a sound banking system - such as good information and risk-management capabilities, a strong legal and regulatory framework, and reliable services in payments, liquidity and securities management will be important for capital market institutions as well. In fact, accelerating capital market development before consolidating the banking structure could lead to a weak circuit.

Institutional investors are the backbones of modern capital markets. They can mobilize substantial resources, increase the liquidity and depth of domestic capital markets, help agents to both overcome information constraints and diversify risks. In emerging countries, venture capital funds can support investments in the small and medium-size enterprise sector, attracting financial, technological and managerial resources from abroad and promoting industrial innovation.

The development of institutional investment, with the support of the banking system, should be accompanied by strong prudential regulation and supervision. These should govern the relationships between banks and their affiliated non-financial and financial firms. In particular, regulations should limit concentrated ownership of banks by non-banks; it should also limit the ways banks can use links with their non-bank affiliates and subsidiaries. Banks, for instance, should not be allowed to transfer risks from these entities upon themselves so as to benefit from government safety nets; also, a bank should not be allowed to monopolize an activity to its own advantage by establishing subsidiaries and affiliates. To this end, banks should be asked to report and disclose information on their affiliates and subsidiaries, indicating ownership, strategy, portfolio and risk structure. ${ }^{28}$ Comprehensive and consolidated supervision of the entire banking industry is essential. A strong legal and regulatory framework, in particular in the area of investor protection, should be put in place for trust in the new institutions to emerge. Investment fund regulation should address prudential rules, custodial arrangements to protect investors in the event of fund insolvency, rules to enhance transparency of funds' strategies. Legislation should also require independent directors on the board of the funds.

To the extent that domestic financial law allows banks to operate in various financial market segments, institutional investors (closed-end funds, mutual and pension funds, and so on) would not weaken the domestic banking industry. In fact, under appropriate incentives, banks may help to build confidence in capital market institutions and investments. As domestic banks enter new market segments trough their affiliates, they would be motivated to strengthen and develop banking services relating to liquidity and securities management necessary for them to operate efficiently in the new fields. Moreover, banks' money management skills (which could be scarce in the early days of institutional investment) could be an asset for new fund managers.

Finally, the investor base could also be enhanced by permitting banks to undertake longterm investment relationships with industrial enterprises (universal banking). Universal banks with high reputational capital can contribute to improving corporate governance; this occurs as their reputation stands to lose from unsound behavior of their client companies. Their long-term interest in client companies gives them an incentive to monitor the company strategy and operations. Universal banks can exert discipline on client companies by pressing executive board decisions and/or by rationing credit. Recent historical evidence - both anecdotal and analytical shows the positive influence that universal banks exerted on corporate business in the US in the pre-World War I period (Chernow, 1997; De Long, 1991). 
Universal banking, however, may suffer from serious weaknesses: first, even good reputation in banking is not by itself guarantee for good competence in industrial matters. Second, the discipline effect vanishes if banks over-extend financial support to insolvent firms, or if they hide to the market important information on their clients, and if they restrain the companies' freedom to search for more competitive sources of funds. Limits to bank holdings of corporate stocks, supervision of banks' governance methods on corporates, and effective incentives for information provision and rule enforcement should therefore accompany the development of universal banking in countries undergoing financial sector reform. In the end, only an open environment where universal banks are forced to compete with a broad range of capital market institutions best protects the health of the bank-borrower relationship and limit abuses.

\section{Managing capital flows}

Especially while the process of reforming the financial sector is still underway, governments may want to consider whether to place, or maintain, temporary restrictions on short-term capital flows. Managing capital flows can prove useful in complementing measures to protect, and to possibly enhance, the reputational capital of domestic financial institutions. Encouraging longterm capital inflows may strengthen the financial circuit.

Although no empirical evidence confirms yet unequivocally the economists' belief that capital account liberalization brings higher growth, financial openness can be regarded to be beneficial to the economic welfare of individuals and societies in the same sense that the creation of a market for financial resources does in any country in terms of better resource allocation and risk diversification. There is also general consensus on the idea that open financial markets and financial market integration exert powerful discipline on national policymakers, putting pressure on them to redress macroeconomic imbalances when these are deemed to be unsustainable.

Experience shows, however, that short-term capital flows could be destabilizing. Shortterm capital - especially trade credit - is essential to keep the economy moving, but when shortterm lenders have weak incentives to take a longer view of the economy, short-term lending may cause circuit breakdowns. In East Asia before the crisis, with restrictions limiting long-term capital inflows, domestic commercial banks raised short-term funds abroad which they then onlent to domestic enterprises. In some cases, domestic enterprises could directly raise short-term finance abroad to fund long-term investments. Foreign lenders underestimated credit risk on domestic borrowers, and the latter overlooked the signs of unsustainable capital accumulation. As a result, short-term capital continued to flow in the region even as long-term domestic savings start fleeing abroad, until the direction was dramatically reversed when risks were suddenly reassessed. Also, circuit discontinuities may have segmented information transmission and distorted the incentive structure of agents operating in different maturity habitats.

While higher long-term capital inflows should be supported, short-term money flows could be controlled, especially early in reform. Government should at least eliminate tax, regulatory and policy distortions that in the past may have stimulated short-term capital inflows. Among distortive factors, a relevant one is the perception of implicit guarantees from the public sector to foreign lenders. When lenders assume that the public sector stands to bail out their losses in the event of borrower default, short-term lending is likely to be more forthcoming than long-term lending, since the value of the guarantee is higher in the short term. ${ }^{29}$

Other relevant distortive factors may hide inside government financial regulations. In the late 1980 s and early 1990s, Indonesia, Malaysia, Korea and Thailand liberalized the current 
account and allowed corporates to borrow short-term funds from abroad, while they kept restrictions on long-term credits and direct foreign investment until as late as 1997 (Thailand) or 1998 (Korea, Malaysia). As a result, corporates reverted to short-term foreign borrowing, with this trend accelerating after 1992 for all four countries (Claessens, Djankov and Lang, 1998). Better regulation can certainly avoid perverse incentives of this type. Also, use of risk-based capital requirements that would incorporate not just credit risk but interest rate and other risks as well might improve the incentive for holding a more balanced portfolio structure in terms of asset and maturity composition. In this respect, the higher the quality of the risk-adjusted capital requirement calculations, the more efficient the lenders' resulting portfolio term structure and capital protection.

A more radical way to deal with circuit stability is the inhibition of short-term capital inflows altogether. ${ }^{30}$ Restrictions on short-term flows may buy time for both domestic financial institutions and supervisory authorities to accumulate more reputational capital. This could be the case, for instance, in India if the authorities pursue further with the second generation financial sector reform and commit to gradually deregulating capital flows. ${ }^{31}$ Restrictions could take various forms, examples of which are: taxes on short-term maturity foreign loans, such as in Chile; limits to tax deductibility for interest on debt denominated in, or linked to, foreign exchange; taxes on foreign purchases of domestic bonds (adopted in Brazil); limits on net open foreign exchange positions of commercial banks (Indonesia); non-remunerated reserve requirements on direct external borrowing by firms (Colombia); ban on sales of short-term securities to foreigners by residents, regulatory prohibition of remuneration of domestic currency deposits held by foreign institutions, and imposition of fees on non-interest-bearing foreign deposits (Malaysia). ${ }^{32}$

Capital restrictions typically bear the inefficiencies that all restrictions to market behavior usually involve. Over time, while their costs increase, their effectiveness wears out as agents find ways to elude controls. In many cases, the administrative nature of restrictions creates perverse incentives to rent seeking from government bureaucrats, and to corruption and fraud.

Policymakers should be very sensitive about the risks involved in adopting restraints. Their use should be justified when, depending on economic contingencies: i) the benefits from greater stability through restrictions exceeds the efficiency losses, or ii) in the context of the reform strategy, temporary use of restrictions may strengthen the incentives introduced with reform. As already discussed, this last point refers to cases where restrictions may help domestic financial institutions build up reputational capital at the onset of reform.

Stimulating long-term capital inflows might improve the maturity matching of domestic investment demand and foreign capital supply, enhance intra-circuit and inter-circuit stability, and induce sustainable investment as risk assessment on lending incorporates longer-term factors. Government should encourage foreign direct investment in the financial sector, which is more stable and brings in knowledge and technology. As already noted, foreign participation in domestic financial restructuring should also be considered by the authorities as a way to increase the franchise value of domestic weak institutions. Government could relieve or eliminate restrictions on foreign investment, such as limits on ownership by foreigners, differential treatments of foreign investors, controls and regulatory requirements delaying the repatriation of capital gains and dividends. Also, as the quality of the information produced by the financial sector improves, developing a strong institutional investor base would help attract long-term savings from abroad that would strengthen domestic investment funding. 


\section{II.2.2 Prudential regulation and supervision}

\section{Strengthening prudential supervision and regulation}

Governments should complement the creation of franchise value by adopting a regulatory regime based on rules designed to align the private incentives of market players with the social goal of financial stability, and by strengthening their supervisory practice.

For the financial circuit to operate smoothly and under stable conditions, creation of franchise value should go hand in hand with development of a strong regulatory and supervisory regime. This should include incentives to align the interests of owners and managers of market institutions with financial stability, and effective enforcement. ${ }^{33}$ The financial sector law adopted in Chile after the 1982 banking collapse, as well as the regulatory/supervisory regime recently adopted in Argentina, are examples of how government can incorporate substantive incentives within the regulatory framework (Calomiris, 1997).

Various measures can strengthen prudential regulation and supervision along marketcompatible principles. First, as domestic banks are allowed to earn extra rents through financial restraints to build reputational capital, a system of sanctions for misconduct should be enacted and strictly enforced. The scheme adopted in the US in 1991 as part of the deposit insurance reform (The Federal Deposit Insurance Corporation Improvement Act) provides a good example of incentive-based corrective measures for under-capitalized financial institutions. The corrective measures - whose intensity varies with the degree of bank under-capitalization - involve: limits on deposit taking, suspensions of dividends, requirement of a capital restoration plan, restrictions on asset growth, approvals required for acquisitions, branching and new activities, ordering of recapitalization by existing owners, restricting inter-affiliate transactions, restricting deposit rates, restrict pay of officers, suspension of payment on subordinated debt, restricting certain other activities, initiation of resolution process, and initiation of receivership/conservatorship.

Prudential supervision could mimic the market also by rewarding prudent and honest behaviors with positive incentives; these could include differential capital requirements based on the quality of internal risk-management systems, reduced supervisory monitoring and fewer prescription rules for institutions judged to be superior performers (Group of Thirty, 1997).

Second, asset growth restrictions could be considered by the supervisory authorities when rapid bank portfolio shifts are observed during reform, threatening the steady buildup of reputational capital. Regulatory restrictions would thus supplement the lack of internal riskmanagement methods and risk-sensitive managers, and curb speculation driven by banks unaccustomed to risk management and yet lured by easy gains from rapid-growing asset prices. Especially early in the reform process, the franchise value of domestic banks is likely to be highly sensitive to the dynamics of asset portfolios, which depends on the portfolios' structure in the prereform stage and on structural adjustment measures introduced with reform (Caprio, 1994). For example, if pre-reform credit programs limited banks' real estate exposures, ending this would lead to investment in property and, possibly, to speculative bubbles (witness Malaysia in the 1970s). Similarly, if the pre-reform environment featured forced allocation of government bonds at below-market rates, ending the constraint could generate portfolio shifts toward higher yielding and riskier investments.

On the other hand, where financial sector reform and real sector's structural adjustment take place simultaneously, uncertainty and lack of information may drive domestic banks to retreat into riskless assets and cut credit to the economy. "Speed limits" on bank asset growth and 
portfolio limits have been proposed (Caprio et al., 1994 and Vittas, 1992), on grounds that rapid loan growth has often been associated with individual, as well as systemic, bank failures. Such limits should aim to ensure risk diversification and a smooth and reasonably sustainable growth. They could embody some flexibility (for instance, they could be linked to the capital ratios of the individual banks) and should be revised gradually to avoid big distortions of credit flows to particular sectors. As in the case of financial restraints, growth and portfolio limits should be time-bound, used to ease the transition from one regime to another (especially in markets with many inexperienced players) and to stymie incipient speculative bubbles.

Third, authorities should place particular emphasis on the strength of banks' financial capital. The Basle Accord on capital adequacy addresses this question directly by setting minimum capital requirements for internationally active banks, determined on the basis of the risk structure of their portfolios. Of course, using capital ratios as a supervisory device for monitoring and enforcing appropriate risk management requires that capital be meaningfully measured. This, in turn, requires clear notions of what constitute capital. It also presumes adequate procedures for evaluating asset quality and for determining proper levels of provisions and loan loss reserves. In short, it requires good accounting practices and sophistication on the part of bank managers and supervisors.

It is a subject of debate whether capital requirements in emerging economies should be higher than in industrial economies. On the one hand, it is sensible to argue that banks operating in a more risky environment should have a stronger capital base. Small community banks in the US, for example, tend to have higher capital ratios that money center banks, partly because their portfolio tend to be less diversified. Inadequate accounting practices, leading to difficulties in assessing capital and assets also argue for a greater capital cushion. On the other hand, several concerns can be raised: higher capital requirements could lead banks to select a point further out on the risk/return frontier, or to disintermediation, or book loans in offshore subsidiaries (Honohan, 1997). Alternatively, to comply with higher capital requirements, banks may be forced to invest an excessive portion of their assets in government bonds which typically bear lower private (and social) returns (Hellmann and Murdock, 1995). ${ }^{34}$ Another limitation is that compliance with capital ratios from a bank may induce complacency both from the bank's management, as well as from counterparties, as to the bank's presumed minimal default-risk standing: management might feel it to be unnecessary to further improve the bank's risk position and counterparties, on their side, might consider for them unnecessary to further assess the riskiness of the bank. Finally, the inadequacy of the static accounting framework, underpinning the capital ratios approach, in tracing the dynamics of the bank's trading strategy; for example, hedging asset positions through collateral margining is not captured by the static assessments of capital adequacy (Nickerson, 1995).

Strengthening supervisory practices and improving ratio calculation better to reflect the riskiness of certain asset categories could help deal with some of the above limitations. Other drawbacks, however, cause the capital ratios approach to generate incorrect incentives. Capital requirements ignore the interaction effects between assets in the same portfolio: if the asset prices show negative correlations, the capital necessary to back the overall portfolio exposure against the risk of counterparty default is less than the sum of the capital requirements necessary to back the asset positions taken in isolation. The same holds if the portfolio comprises mutually offsetting claims on income flows (such as, for instance, two identical swaps with the same counterparty, of which one would be the reverse of the other), as not all claims can have positive market value at the same time. Disregarding these factors may resolve in much higher capital requirements than necessary, with considerable inefficiencies in resource allocation, undue costs on the banks, and a weakening of their international competitive position. 
The preceding limitations suggest some useful policy indications. Where resource constraints make even minimum capital requirements excessively costly for individual banks, it would be advisable for regulators to accept lower capital ratio levels and to build from there gradually as the financial conditions of the banks improve over time: slow and gradual movements, but consistent with the overall policy objectives, are better and ultimately conducive to credibility than more ambitious but unsuccessful attempts to jump to high standards. Moreover, capital ratios should be consistent with the projected profitability of banks and the amount of public support that is available.

Transitional measures could be introduced to cushion the effects of new accounting practices on asset valuation, giving banks more time to adjust to new rules without weakening them. For this to be successful, however, authorities should pre-commit publicly to the endtargets and the timeframe. They should explain to the public the reasons for agreeing on lower requirements and that they hold institutions to the announced standards. This would put the credibility of policymakers at stake and give governments an incentive for time consistency. Regulation should force the authorities to take graduated action with financial institutions showing problems, possibly in accordance with a pre-defined sequence of policy steps; this would limit their flexibility in deciding when and whether to intervene in individual cases, and would bound them to take transparent decisions on forbearance.

Furthermore, as banks develop their own risk-management capacity and increase their activity in the international markets, they should be advised - and assisted - to replace static capital ratios with more advanced methods for economic capital allocation ${ }^{35}$ that would allow them to economize on resources and reflect more correctly the risks associated with financial instruments and counterparties. This is consistent with the Basle Capital Accord (PadoaSchioppa, 1996); it would make the effects of risk diversification more visible and directly measurable, and would strengthen the banks' incentives to diversify their portfolio. Progress toward the adoption of more advanced risk-management systems would require: (i) greater technical competence on the side of regulators, who would be called upon to assess the soundness of the methodologies adopted by the banks, and to verify their effective implementation; (ii) collection and dissemination of data and information necessary to feed the risk-management; and (iii) technical assistance to bank traders and supervisors to acquire and maintain the necessary expertise.

As more advanced risk-management systems are introduced, new market regulations should: 1) require banks to disclose their market and credit risk position; 2) require banks to raise their capital if this shows to be insufficient to back their reported risks; 3) prevent banks from deliberately underestimating their potential losses by requiring them to put up some extra capital in the event that actual losses exceeded the ex-ante estimations (i.e., restore their capital or maintain higher ratios as a penalty); 4) prohibit banks from undertaking speculative activities, at least until they have reached a high level of reputational capital; and 5) as banks are allowed to undertake such activities, require them to separate hedging from speculative positions and to place the latter in separate subsidiaries or affiliates. ${ }^{36}$

\section{Adopting incentives-based safety nets}

Safety-nets to reduce systemic risk should minimize the moral hazard from stakeholders by limiting risk protection and by making the cost of protection sensitive to the risk taken. 
The circuit is vulnerable to financial crises. The perception of an increasing systemic risk may lead market participants to interrupt the flow of funds causing circuit breakdowns along the process, and eventually a major circuit collapse altogether. Moreover, the fiscal costs of resolving systemic crises and their effects on output understandably make governments acutely aware that measures must be taken to avoid them and keep the circuit running - typically, through lending of last resort and central bank liquidity facilities for payment systems, conservatorship, and insurance of bank deposits. The following discussion focuses on the incentive structure underlying deposit insurance. ${ }^{37}$

In many countries, the safety net adopted by governments is deposit insurance. Depositinsurance schemes differ across countries. In most cases, deposit insurance amounts to an implicit government promise of loss coverage from the public budget; that is, bankers and depositors assume that government stands ready to absorb banks' losses if there is a crisis. More formal schemes with explicit insurance terms and covenant rights are becoming increasingly popular. Whatever the form, deposit insurance schemes are intended to prevent bank runs, thus eliminating a principal cause for transmitting financial shocks throughout the circuit.

Experience in both industrial and emerging economies has shown, especially in the 1980's, that financial risks are not entirely exogenous and that most are deliberately taken by institutions and individuals acting upon knowing that they are protected by some form of public insurance. ${ }^{38}$ Circuit breakdowns of huge proportions have been in countries with deposit-insurance arrangements and, as it turned out, some of these were themselves a destabilizing factor through perverse incentives to aggressive risk-takers.

Moral hazard is a serious problem. With deposit insurance, bank managers need to be less concerned about the potential impact of their decisions on depositors and, hence, on the banks' reputational capital. For the same reason, depositors have less of an incentive to monitor bank managers, or to assess the reputational capital of banks where they deposit their money: the government protects their money to some extent, anyway. On the other hand, if depositors did monitor bank managers scrupulously, bank runs could happen and have systemic consequences, possibly involving sound financial and non-financial institutions together with defaulting ones in insolvency or serious illiquidity problems.

From the overall effect on welfare, the debate on safety nets has recently turned to discussing their incentive structure: policymakers are interested to know how to retain the positive features of a public safety net while limiting its moral hazard effects. ${ }^{39}$ Consensus seems to converge on the idea that deposit insurance should be explicit, with limited coverage and mandated membership, and with government powers to promptly intervene in weak participating banks, although implicit guarantees are usually ambiguous, which should make agents sensitive about the risk of not being bailed out. Clearly, this assumes that the terms of the arrangement are fully credible. If credibility is lacking, explicit insurance schemes may even increase moral hazard to grow.

Explicit schemes could be designed to provide coverage only for small deposits, so as to protect agents - i.e., small depositors - with greater information costs and lesser incentives to monitor and exert governance on banks. It is held that large, uninsured depositors would discipline banks as they would stand to lose if the bank defaulted. However, to the extent that large depositors can split their deposits into series of small deposits the system can get spoiled easily. Alternatively, the insurance could cover a large constant fraction of all deposits: all depositors would retain an incentive to respond to changes in bank risks. In practice, what appears to be a very difficult task for the government is to identify the optimal insurance 
coverage. On one side, the coverage must be low enough to give depositors the right incentive to monitor their banks; on the other, in the event of a high perceived risk of financial instability, too low a coverage might not prevent deposit runs and would thus make insurance purposeless.

Bank discipline might be improved if insurance premiums were correlated with bank risks. Stronger discipline could also be attained if small depositors had an incentive to monitor banks. Limited insurance coverage would likely induce both large and small depositors to consider more carefully their bank risk. A strong incentive would hold if depositors were asked to pay insurance premiums correlated with bank risks. The incentive would be strengthened further if insurance services were to be provided by competing private insurers. As private insurance would be pressed to correlate premiums with bank risks (certainly under stronger pressure, and with better capabilities, than government bureaucrats), the demand for information from banks and their pressure for good bank governance would be considerable. However, in the absence of means to control bank risks effectively, determining the "right" premium remains a very difficult undertaking since banks can always take on more risks than those reflected in the premiums.

An alternative to reform the incentive-structure of deposit insurance is a subordinate-debt requirement (Keehn, 1989; Wall, 1989; Calomiris, 1997). This scheme relies on the "informed agent" assumption. Banks would be required to finance a small portion of their non-reserve assets with subordinated debt (uninsured certificates of deposits), bearing interest not greater than the riskless rate plus a given spread. Under such constraint, all bank debt should carry risk-premiums within the given spread. Holders of subordinated would be well informed market participants who faced the tradeoff between holding a higher-earning bank liability and receiving no protection from bank default. Subordinate-debt holders would have an incentive to monitor that banks keep their overall portfolio risk consistent with the maximum risk-premium requirement; their superior information would allow them to dispose of their holdings as bank risk were to evolve inconsistently with the requirement. The limitation on the yield spread would also help the insurer to set insurance premiums closer to the true risk of the banks (Calomiris, cit.).

This incentive mechanism would supply the market with reliable signals on behavior of banks, provided there was a liquid secondary market for the subordinated debt, and that the requirement to issue the debt was credible and effective in the first place. For this purpose, banks should not be allowed to purchase their own debt, or to overprice debt with sidepayments to debtholders (Calomiris, cit.).

An alternative to safety net is "narrow banking". A narrow bank, chartered within a bank holding company, would issue insured deposits fully backed by low-risk, market-priced assets. All other bank holding company's operations would be unregulated, and deposits outside the narrow bank would be restricted to uninsured time deposits. However, to the extent that banks can lure depositors into uninsured short-term deposits bearing higher yields, the narrow banking scheme would still leave the system unprotected and banks vulnerable to runs in the event of perceived risks by depositors. In the light of such vulnerability, narrow banking is not politically credible as bank runs could still be used to motivate government interventions to protect uninsured deposits.

At the heart of all forms of safety net thus lies a fundamental incentive problem relating to the credibility of the government implementing the safety net and its ability to commit itself to avoiding bailouts. Both explicit (limited) deposit insurance and narrow banking lose their rationale if they fail to alter depositors' perception as to the likelihood of government intervention in the event of systemic crisis (Honohan, cit.). 


\section{Encouraging self-policing}

Incentives to build a strong reputational capital and to increase the franchise value of financial institutions may result from the interest of individual market participants to establish long-term mutual bonds that ensure honest and prudent behavior through self-policing. Government should encourage the adoption of self-policing by supporting private-sector cooperative arrangements at the industry level and should closely monitor their progress. Such arrangements can significantly improve circuit stability by providing efficient and safe financial infrastructural facilities.

Enforcement is a key ingredient for the integrity of the financial circuit. Very often, poor enforcement, rather than lack of rules, is the cause of financial sector problems, especially in developing economies. Institutions that provide people with incentives to mutually monitor their action can help enforce rules for the stability of the circuit. Incentives to build a strong reputational capital and increase franchise value may result from the interest that private-sector agents take in establishing long-term mutual bonds to enforce honest and prudent behavior through self-policing. Self-policing is particularly effective in contexts where individual behavior affects the financial returns to the other participants, Effective self-policing increases the franchise value of institutions with higher reputational capital and induces investment in reputational capital. By doing so, it enhances the overall stability of the circuit process.

Spontaneous self-policing arrangements can be found in the history of international trade and commercial law, public security and maintenance of public services, and commercial bank clearinghouses. ${ }^{40}$ In developing countries, such arrangements are common for governing and managing natural resources (Ostrom, 1990). Self-policing arrangements allow participants to undertake transactions that would otherwise be unprofitable due to high transaction costs. ${ }^{41}$

Self-policing arrangements may develop within financial communities as well (Goodhart, 1986). In some cases, they evolve into fully fledged self-regulatory organizations (SROs), with internal statutory rules, financial resources, and formal structures involving shareholders, managers and employees, codes of conduct and oversight procedures (Glaessner, 1993). Many countries today adopt SROs in payments and securities markets. SROs could range from interbank deposit markets, to wholesale and retail payment systems, securities trading and stock exchanges, securities lending and settlement clearinghouse services, deposit insurance, credit information sharing systems. SRO responsibilities could encompass regulation of market transactions (listing requirements, market and system surveillance, trading regulations, clearing and settlement, information disclosures); regulation of market participants (admission and licensing, capital requirements, business and ethical conduct); disputes resolutions and enforcement actions, including those that deal with insider trading. SROs can play a significant role in ensuring the smooth functioning of vital links of the circuit.

The underlying rationale of SROs is to exploit the self-interest of members by rewarding compliance with rules and punishing non-compliance with commensurate returns/losses on reputational capital. Members ultimately face the risk of losing their entire reputational capital by being ostracized by their peers. SROs place reputational capital at the center of the enforcement mechanism; by doing so, they reduce transaction costs associated to limited information and incomplete trust. Mutual bonds in financial SROs typically involve:

- admission criteria: the selection of new members tend to determine the adequacy of their reputational capital. ${ }^{42}$ Institutions wishing to enter the community in light of expected profits have an incentive to invest in reputational capital; 
- rules of conduct governing member relationships and their business activity. Compliance with rules is what allows for transaction costs to be reduced, and ultimately represents the benchmark against which the value of the reputational capital of each member is assessed by the others;

- rules for information provision, governing disclosure, sharing and reporting of information. Information is what keeps the incentive mechanisms alive and going: with limited information or with deliberately hidden information about past behavior of community's members, there are no incentives for honest and prudent behavior;

- sanctions for non compliance (including suspension and exclusion). Members must be motivated to execute sanctions against non-compliant behaviors.

Incentives in financial SROs - especially in interbank payment and settlement systems - can be strengthened by members agreeing to individually pre-commit resources - in the form of mutual lending obligations or collateral pooling - that would be mobilized in the event of one or more members running into illiquidity or insolvency problems. Pre-commitments to liquidity- and loss-sharing arrangements generate incentives for each member to monitor the behavior of the others, to agree on and to enforce information disclosure rules, and to take action in case of misbehaviors.

Liquidity and loss-sharing arrangements protect the circuit from the systemic consequences of failures of one or more financial institutions. They thus afford supervisors some higher degrees of freedom in deciding whether to let insolvent institutions fail, and enhance the certainty of government exit policies. To the extent that greater certainty lessens the agents' expectations of government bailouts or forbearance, financial institutions are faced with a stronger incentive to good conduct.

Some problems may complicate the setting up of financial SROs in developing countries. Scarcity of institutional and human resources may constrain the quality of oversight, and lack of reasonably homogenous institutions could impede the formation of internally balanced structures. Moreover, with limited competition in securities markets, self-regulation may not be enough to ensure safe and efficient markets. Also, SROs might transform themselves into cartels and jeopardize competition. Finally, short-term tensions between market development objectives and the SROs' authorities - such as, for example, on the looseness of listing requirements - might resolve either in discouraging participation, or in diminishing long-term confidence in the market.

Even so, financial SROs in emerging economies could help improve the efficiency-stability tradeoff. Because of their knowledge and experience, and because of their commercial interest, SROs are better placed than government bureaucrats to design rules consistent with the operational features of their business, to keep their operational processes and infrastructures apace with technological progress, and to improve their business standards. In particular, since information is vital to each SRO member, the SRO setting is better positioned than government regulatory agencies to achieve enforcement of disclosure rules through peer monitoring. Also, by being part of the industry, SRO owners and managers have an incentive to keep up with the institutional and organizational developments in the industrial economies. Furthermore, the SRO model offers an appropriate institutional setting to develop market microstructures that facilitate securities trading and market liquidity across the circuit.

Government has a key role to play in supporting the formation of financial community ties along self-regulatory principles. It could delegate to domestic financial institutions the task to form industry groups for governing and running specialized markets. SROs should organize themselves, address the planning and operational issues, identify functions, rules and codes of 
conduct, setup oversight mechanisms, all under the supervision of the relevant public authorities. Participants to SROs could be called upon to share in the financing of the investment and operating expenses involved in its functioning.

Through direct involvement, the process would lead SRO members to seek transparency from each other. Information sharing through institutional and interpersonal communication would help members develop better relations. Similarly, consultation between members and supervisors would help both to gain a better understanding of their respective positions, and improve their cooperation.

The efficiency of dispute resolutions and adjudication processes is crucial for the success of SROs. ${ }^{43}$ Government should not preclude (indeed, it should encourage) private judicial mechanisms and institutions that serve to enforce good conduct. This would be particularly useful in countries with slow judicial processes and where the general orientation of the law is biased against private commercial practice. In a number of cases, out-of-court procedures have been successfully employed to govern corporate restructuring processes (Claessens, 1998).

By adding strands to the web of restraints that curb imprudent and honest behavior, SROs can strengthen the financial circuit. They should be seen as complement of, rather than substitute for, prudential regulation and supervision. Government should monitor their operation and intervene promptly if their action deviates from their purposes. Government should ensure that SRO rules are fair and based on stability and efficiency principles. It should protect market competition and ensure that SRO information, monitoring and sanctioning systems are compatible with fair competition. In particular, government should assess SRO entry and sanctioning criteria, and ban discriminatory and unfair practices. Government should also ensure that SRO rules and operations are not detrimental to small participants and consumers, and that underserved constituents have fair access to their services.

Supervisory authorities should ensure that SRO members, shareholders, managers and employees have proper incentives. They should make sure that members are fully aware of the risks of their business, and that their risk-management capacity is sufficient to make the market robust and resilient against large financial and operational shocks. ${ }^{44}$ For SROs governing and running technical infrastructures, government should make sure that their technical and operational capacity is adequate and well-maintained.

\section{II.2.3 Information}

\section{Enhancing production and conveyance of information}

A critical component for the smooth functioning and integrity of the circuit is the improvement of the quality and quantity of available information. To the extent that financial institutions invest in reputational capital and financial investors have an interest to combine risks and returns efficiently, there are considerable incentives for information to be searched and supplied, and for specialization and cooperative arrangements to arise in the business of information provision. Governments can greatly improve incentives for optimal provision of information.

The discussion of SROs has underscored the importance of information for making sanctioning systems effective. Information permits the incentive mechanism to work and 
enhances the franchise of the agents with higher reputational capital. Information is essential for the smooth functioning and integrity of the circuit in a decentralized-decision environment, as intra-circuit and inter-circuit stability depends crucially on the reconciliation of decisions from capital good producers, investing companies, and savers. As stability requires agents to deploy a high reputational capital, information is necessary to signal efficiently across the circuit the true level of reputational capital of individual agents: inadequate information would weaken the incentive to investments in reputational capital, shorten the agents' time horizon, and raise the potential for profit from imprudent and dishonest behavior. A critical component of financial sector reform is thus the improvement of the information generation and dissemination process. Investors need to know about the creditworthiness of financial intermediaries and the quality of financial services they purchase, just as intermediaries need to assess the reliability of their counterparties and borrowers, and need to know about their misconduct.

Government action to set the right incentives can help a private market for information to develop. Information provision involves two stages: production and conveyance: searching, inspecting, testing, evaluating, interpreting and judging are parts of the production process of information; disseminating information to the general public through reports or advertising campaigns, and providing individualized information to specific inquirers are ways to convey information (Klein, 1997b). Provided that financial institutions have invested in reputational capital and that investors have optimize their risk/return tradeoffs, there are incentives for information to be searched and supplied.

On the demand side, sensitivity to capital losses motivates investors to use information to screen, select and monitor intermediating financial institutions to minimizing risks of loss, directly or through specialized institutions. In developing countries, where banks represent the largest share of domestic financial markets, governments should exploit the interest of depositors in sound banking and use it to improve the supply of financial information. Reliable and timely information is essential if market participants are to accurately judge the quality and strength of banks, and to reward or punish them according to performance and risk-taking attitude. ${ }^{45}$

Market demand for information would prompt the intermediaries seeking to enhance their reputation to spontaneously provide reliable information. For example, where there is a subordinated debt requirement for banks, healthy banks have an incentive to disclose their true status, so that subordinated-debt holders, otherwise unable to discriminate good from bad banks, do not indiscriminately sell their holdings in the face of aggregate shocks.

Information transmission is critical also for the buildup of reputational capital. As we learn from consumer choice theory, the reputational capital of an agent operating in a large, competitive market is not only sensitive to her repeated dealings with the same counterparties, but also to extended dealings. An extended dealing occurs when a supplier's customer shares information with other agents on the quality of service received. Through extended dealings, the reputational capital of an agent can be assessed prior to dealing with her. In financial markets, institutions with a high franchise value seeks to exploit extended dealings by disclosing more information to their clientele (Hellmann et al., 1995).

This incentive may increase under regulation allowing banks to operate in various segments of the capital market, since reputational capital in one segment affect franchise values in other segments. This, on the one hand, makes it easier for a well-reputed bank to establish itself in new business ventures; on the other hand, it gives the bank an incentive to act prudently and honestly in the new segments as misbehavior could damage her reputational capital across all segments. 
The same incentive may be generated by allowing financial institution to operate across the whole maturity spectrum. If banks are restricted to operate either in short-term or long-term activities, incentives could more easily lead short-term lenders to overfinance capital good production and to possible circuit breakdowns. If banks are allowed to operate across the whole maturity spectrum, they have more information on long-term market conditions and have incentives to use information efficiently, since imprudent behavior could cause them to lose in all maturity segments: a bank that lends short-term to capital good producers, but that also has an interest in the long-term investment business, is likely more cautious in taking extra short-term risks if it knows that investment demand is drying up in the economy, or that real capital profitability is declining. The internalization of information within the same institution may thus enhance intra-circuit and inter-circuit stability by reducing the incentive to overfinancing.

The demand and supply factors just discussed generate conditions for agents to specialize in the provision of financial information. Credit bureaus, rating agencies, securities underwriters are examples of financial information providers that facilitate investors' decisions by reducing information asymmetries. Interbank information sharing on borrowers, for example, is shown to increase lending volumes where safe borrowers are otherwise priced out of the market due to adverse selection (Jappelli and Pagano, 1991).

Information can be provided uniformly and disseminated widely through, for instance, periodic standardized reports on financial institutions, or it could be customized for individual clients. Matching or referral services - such as the well-known accreditation schemes in the US health sector - could also be provided by private sector agencies to inform clients about quality, terms and conditions to be expected from individual financial institutions. Financial referral services can rely on information disseminated by public agencies or made available by the financial institutions themselves, and on clients' evaluations, opinions and satisfaction rating. Referral services involve a reputational mechanism which would provide a channel for financial institutions to advertise their reputational capital to new potential client investors and service users on the basis of verifiable and tested information. Information providers might be either profit or non-profit outfits.

Providers of customized information might operate for a profit and sell specialized reports for a fee. If information is proprietary, its production can be profitable. Providers of uniform information might organize themselves as consumer unions or producer cooperatives and be remunerated by their respective communities (Klein, 1997a). In the case of interbank systems for credit-risk information sharing, for example, increasing returns associated with additional participating banks tend to make the systems operate as natural monopolies (Jappelli and Pagano, cit.); in this case, they might organize themselves as SROs.

Government can play an important role in the provision of information. It could subsidize for a while one or a few private enterprises until a market takes off. Through SROs, the government could induce private-sector financial institutions to set up information services for their mutual benefit and for the benefit of clients. Government could initially provide information services directly, as in the case of the Central de Deudores in Argentina, and later let the private sector take over (Calomiris, 1997; World Bank, 1998).

Government could also provide infrastructure that would ease the flow of private information. It could disseminate information on bank credit risk collected in its banking supervisory capacity, and establish a centralized registry for collateral. Information on bank credit risk would provide basic inputs for more analytical assessments by specialized institutions, who could cross-check or combine that information with other market or network information. ${ }^{46}$ It would also make it possible for rating agencies to credit-score smaller firms which normally do not get ratings, thereby enabling these firms to have access to financial services otherwise 
inaccessible to them. A centralized registry for collateral interests would avoid improper information on collateral use and would therefore help lenders make better decisions on lending volumes and allocation. ${ }^{47}$ Furthermore, the government could support the training of professionals in financial information (accountants, auditors, market-survey specialist, IT experts, economists). Finally, the government could compile and disseminate statistical information necessary for the more advanced risk-management technologies.

International discussions are currently debating the idea to promote incentives for sound finance through an international rating of financial systems. Governments could ask to have their financial systems and regulatory/supervisory regimes rated by one or more specialized bodies peer groups, private rating agencies, official bodies, and so on. The rating, which would be made public, would evaluate domestic policies and quality of domestic regulation and supervision, and make qualitative assessments. This would almost certainly alter the incentives of governments which do not abide by international standards of sound financial practice to take corrective action, especially to the extent that ratings affected a country's borrowing costs.

Sound information provision may significantly improve the incentive structure of the circuit process. Information providers, however, should not replace supervisors, but complement them. Even with good information, the circuit remains vulnerable to bouts of over-enthusiasm and over-pessimism, when agents tend to alter the value of information and overreact to it depending on what they expect others to do. Thus, close monitoring of markets and institutions by well-trained supervisors is necessary, as well as clear and timely policy responses from them to abnormal conditions.

\section{Strengthening informal finance}

\section{Governments should exploit the informational comparative advantage of informal financial institutions and strengthen the complementarity between the formal and the informal sectors.}

The poorest people of rural and urban societies live beyond the frontier of formal finance, or outside the formal financial circuit. Here, credit is scarce, costly, and related to social ties. Financial transactions are personalized and often conducted directly, or through informally established groups or institutions. Savings are held in cash or secure real commodities, and often lent to relatives or friends on terms of reciprocal assistance. If an economy is to develop, it needs to progressively allow for the transition of its informal actors to the formal circuit. Incentives can help.

Informal financial service providers have an incentive to deal with small amounts of money and to interact with people spread widely across the country. They do not carry the cost of documentation and bookkeeping, and act upon information exchanged through face-to-face relationships and on rules enforced through social control. This makes honest informal intermediaries much better placed than formal institutions and government agencies to reach out effectively to people beyond the frontier, and to implant the principles of a market credit culture. Experience shows that informal low-cost remittance networks can provide efficient money transfer services to immigrant workers; that rotating savings and credit associations and, in general, self-policing arrangements based on strong social ties, can effect stable term transformation of liquid funds and fund long-term investment projects; that the social mechanisms of information provision and rule enforcement allow informal lenders to tailor their loan terms and conditions upon the specific characteristics and the needs of individual borrowers, overcoming the rigidities typically embedded in the standards conditions of official finance. 
The modern approach to informal finance seeks to exploit the comparative advantage of informal financial institutions (Yaron, et. al, 1997). Reforming the financial sector in developing countries should aim at strengthening the complementarity between formal and informal sectors. Formal financial institutions who do not find uneconomical to deal with informal borrowers directly could operate through informal lenders; these would act as second-layer intermediaries: large pools of small savings could be placed in formal financial institutions and thus benefit from greater diversification and higher returns. Similarly, savings from the formal sector would flow into informal-sector projects, something that would not normally happen. While formal institutions could lend to the second-layer intermediaries against collateral, end-borrowers may not have to pledge collateral. A well consolidated example of such form of complementarity is offered in India by the non-banking financial companies sector (Pahwa, 1998).

Another important advantage of any informal-formal link is that formal financial institutions would have an incentive to select the best informal service providers, and so eliminate the low-quality ones from the market. The franchise value of those informal providers doing business with formal institutions will increase Indeed, they would seek out ties with the formal sector, a powerful incentive to strengthen their reputational capital by serving their community fairly and efficiently. One example of successful links between the formal and the informal sectors is offered by the monyeshops in the Philippines (Von Pischke, 1991).

Informal financial service providers must be able to price their services consistently with the need for a fair return on the risks taken, and should be permitted to offer saving- and transaction-services to their customers (for instance, saving and deposit accounts, money transfers and payment services). Such services would enhance the information content of the relationship between the service provider and her end-users, as they convey more information on the income and payment time-profile (and, ultimately, on creditworthiness) of the loan customers, and supply end-users with means to test the reliability and accessibility of providers. In close communities, saving and transaction services increase the loan customers' incentive to repay their loans, knowing that loans effectively come from their neighbors rather than distant, anonymous agencies (Vogel, 1984). Furthermore, these services contribute to the formation of larger financial savings by inducing small rural savers to convert their accumulated tangible stores of value (jewelry, livestock, cash) into higher-yielding and more liquid financial assets. By doing so, they add to the liquidity of the economy.

The government could also induce informal self-policing in rural and urban communities, where ethnic bonds are stronger and some local leaders have a high reputation, by exploiting the opportunity for low-cost information sharing and peer-pressure mechanisms that are typical of small communities. Through peer-monitoring informal self-policing would improve considerably the borrowers' debt- repayment capacity and lower transaction costs associated with lending to informal borrowers (Stiglitz, 1993). Government should seek to gain firsthand knowledge of developments and conditions in the informal sector through regular direct contacts with the local communities of informal service end-users and through ad hoc surveys and research activity. Government should sanction informal providers who imposed unfair and exploitative terms on loan and service customers, or endangered the trust basis of their communities, and should ensure viable conditions for those who maintain a high reputational capital and serve their community well.

In the longer term, incentives in the informal financial sector would strengthen the domestic base of savers and borrowers, and increase the quality of resource allocation and use in those parts of society otherwise condemned to stagnation and poverty. Government should thus refrain from imposing plans that defy economic incentives like, for instance, forcing formal 
institutions to undertake unremunerative activities in support of agents outside the frontier. Allowing informal financial service providers, as suggested above, to expand the range of services offered outside of the frontier and to price such services in line with the risks taken is a first important step. Government should also strengthen the debt repayment capacity of the agents beyond the frontier. Investments in physical infrastructure in poor rural and urban areas - for example, in the transport and telecommunications sectors; introduction of greater flexibility in price and wage regulations that stimulate commodity supply and labor employment; improvements in enforcement of contracts and property claims; regulatory reforms in land titling and registering, and extension of information services, can all very often trigger significant changes in the income generation capacity of the local people and prod their entrepreneurial spirit with relatively modest public spending.

Likewise, governments could help the best performing informal service with technical and financial assistance on accounting techniques, financial practices (such as asset and liability management), project evaluation, and performance analysis, monitoring, managementinformation and risk-management systems. Government could mobilize resource expertise both to identify technologies and projects best suited to local community needs to be supported through informal financial services, and to train informal service providers to work out with local borrowers more favorable loan repayment terms and conditions, and contingency provisions. 


\section{Appendices}

\section{Appendix I. Sequential structure of the CTF model}
(A.1)

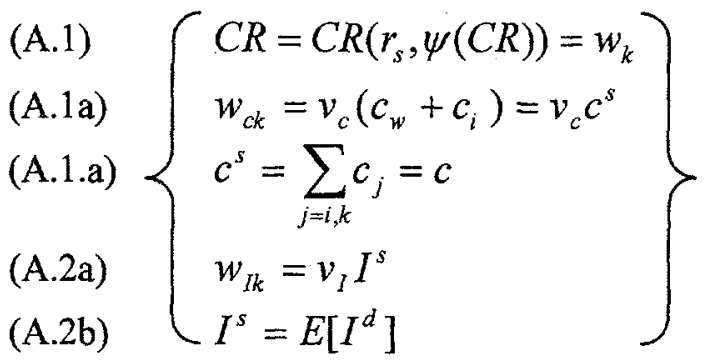
Production
(A.1a)
(A.1.a)
(A.2a)
Production

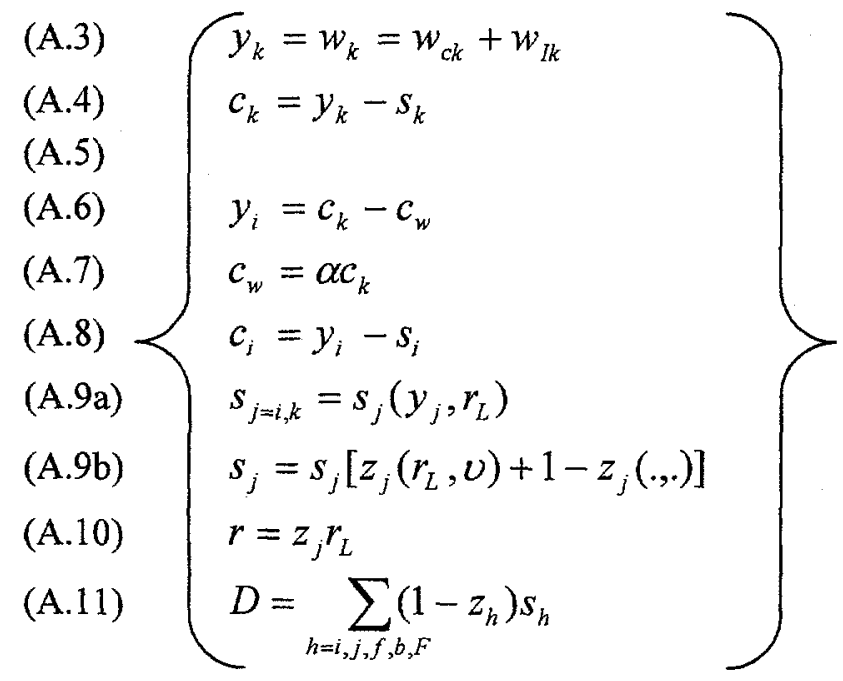

Household

income-

consumption-

saving

(A.12a)

$I^{d}=I^{d}\left(\mu-r_{L}^{-}\right)$

(A.12b)

$\mu=\mu\left(K_{0}+I\right)$

(A.13)

$L F^{d}=I^{d}$

(A.14)

$y_{F}=q L F^{s}$

(A.15a)

$L F^{s}=\sum_{h=i, j, f, b, F} z_{h} s_{h} \leq S$

(A.15b)

$L F^{s}=L F^{s}\left(r_{L}^{-}, r_{L}^{-*}\right)$

7

(A.15c) $\quad r_{L}^{-}=r_{L}+q$

(A.15d) $\quad r_{L}^{-*}=\left[r_{L}^{-}-\phi\left(r_{L}^{-}\right)\right]_{\max }$

(A.15e)

$L F=I=\min \left[L F^{s}, L F^{d}\right]$

Investment financing

Investment funding

(A.16) $y_{f}=I+c-w_{k}$

Gross corporate income 


$$
y_{b}=\psi^{-} C R r_{s}
$$

Bank income

$$
S=\sum_{j=i, k} s_{j}+y_{f}^{n}+y_{b}+y_{F}
$$

Saving

\section{Appendix II. Saving in CTF}

The model described in the text represents a logical circuit of income generation. Its dynamics springs from autonomous (exogenous) spending decisions. As this appendix shows, such dynamics is throughout conditioned by the interactions of individual spending (saving) decisions. Within the circuit, individual spending (saving) decisions are affected by decisions taken by agents placed up-front in the circuit, who either have access to external financing or receive their income earlier in the sequence. The circuit determines the residual (or passive) nature of aggregate saving (i.e., aggregate saving always equals aggregate exogenous spending), notwithstanding individual households' saving plans, and whether or not agents behave optimally in this respect. Below, a simple sequence analysis of model's responses to changes in selected variables shows the following propositions to hold in a closed economy:

Proposition 1. For any given level of aggregate investment, changes in individual or sector savings do not affect the volume of aggregate saving, although they affect the economy's saving ratio.

Suppose that, with $I$ given at $I^{\wedge}$, agent $k$ increases her current consumption temporarily, while agent $i$ keeps hers unchanged. As a result, $c_{w}, c_{i}$, and $y_{f}$ increase correspondingly. ${ }^{48}$ If $f$ saves the extra income, it directly offsets the initial drop in aggregate saving caused by $k$. But the same result holds if firm $f$ decides to put the extra income into new production: new household income is generated to the point where additional savings equal $f$ 's extra spending. In the end, aggregate saving remains unchanged, although aggregate output has increased.

Aggregate saving remains unchanged, too, if $k$ decreases her consumption: household $i$ might either absorb on herself the demand shock by reducing her saving equivalently. From E.1, the reduction in $i$ 's saving is such that $-d s_{i}=\gamma d s_{k}$ and the effect on $f$ s saving is

$d s_{f}=(1-\gamma) d s_{k}$; thus, the change in aggregate saving is

$d S=d s_{k}+d s_{i}+d_{f}=d s_{i}-\gamma d s_{k}-(1-\gamma) d s_{f}=0$. Alternatively, agent $i$ might contravene to her Euler condition, keep saving unchanged, and pass the full demand shock on to firm $f$. This would see its income and saving drop by an equivalent amount. Again, no change in aggregate saving could occur. These results yield irrespective of how agents plan to allocate their income intertemporally. ${ }^{49}$ Assume now that agent $i$ increases her saving: $i$ 's lower consumption decreases both $f$ s income and saving correspondingly; therefore, aggregate saving does not change and aggregate income falls. If the increase in $k$ 's saving is permanent (due, for instance, to a change in $k$ 's rate of time preference), $I$ may react in two alternative ways: she may either incorporate the new information in her optimal saving plan and reduce intertemporal consumption as her income drops permanently; or she could behave outside her Euler rule and keep consumption unchanged: saving would drop enough to offset the initial increase in $k$ 's saving. The result is the same if the additional saving originates from the corporate sector through, say, a cut in $f$ 's wage costs. The 
impact of $f$ s larger saving would alternatively determine: an equivalent and permanent reduction in $k$ 's consumption (which would ultimately feed back on $f^{\prime} s$ sales), if the original change were perceived to be permanent by both $k$ and $i$; or an equivalent and temporary cut in $k$ 's saving, in case the change were perceived as temporary; or a combination of the two. But, in each case, the final effect unambiguously consists of offsetting changes in individual or sectoral savings somewhere in the economy that leave aggregate saving unchanged.

It can be shown that the invariance of aggregate saving for a given aggregate investment obtains even if the agents mistakenly believe the initial changes in individual, or sectoral, savings to be permanent (resp., temporary) when in fact they are transitory (resp., permanent).

\section{Proposition 2. Changes in aggregate saving can only result from changes in the level of} aggregate investment.

Consider an increase in $I$; this translates into an equivalent increase in $w_{k}$ (below, the case is also considered where the increase in $I$ does not fully translate into an equivalent increase in its production cost). If $k$ perceives the increase to be temporary, optimality requires her to save it all: no income change is transmitted to other agents, and aggregate investment, income and saving all increase by an amount equal to the initial increase in $I$. On the other hand, if $k$ perceives the increase to be permanent (i.e., she expects $w_{k t+1}$ to increase by the same amount), she decides to consume the additional income and alters optimal intertemporal consumption accordingly. Moreover, if agent $i$ does not change her saving patterns either ${ }^{50}$, the increase in her current and future income goes fully into consumption, and $f$ 's profits increase correspondingly. In the end, whether firm $f$ saves its profits, or uses them in production, aggregate saving increases by as much as investment (see case under proposition 1). The same holds even if $i$ does not follow her optimal rule and saves the additional income from $k$ 's larger spending.

The result holds also in the general case that the increase in $I$ exceeds the increase in its production cost (as production adds value): the difference corresponds to $f$ 's real capital accumulation, and represents a positive (non-monetary) contribution to corporate (undistributed) profit (i.e., corporate saving), which would just make up for the less than proportional increase in corporate income from household consumption.

\section{Proposition 3. Changes in the interest rate do not affect aggregate saving, although they may} alter its composition.

Assume that $I$ is given, and assume that a change in $r_{L}$ increases households' desire to save. In a model without interactions, the increased savings of individual households directly translate into larger aggregate saving and, hence, into a larger supply of long-term funds. With interactions, this cannot happen. Note first that, from Euler condition E.1, the adjustment in optimal saving from agent $i$ is smaller than is the case without interactions, given the feed back of $k$ 's increased saving on her income. But whatever the households' response to interest rate changes, any change in their saving is one-for-one reflected in the income and saving of the corporate sector. Aggregate saving remains unchanged - although its composition has changed and no extra resources can be made available for additional long-term funding, even though financial investors fund supplier are more willing to invest their funds at the new, higher interest rate.

Interactions and sequencing across the circuit may generate considerable coordination problems. Changes in the rate of interest simultaneously affect the saving plans of all the agents in the economy. The revised saving plans may, or may not, all be mutually consistent and thus optimal..$^{51}$ In the event of coordination failures, some saving plans are invalidated ex post, with some agents ending up with larger (or smaller) savings than desired: it is not possible for all 
agents to simultaneously change their savings to the new desired levels. Invariably, however, aggregate saving eventually adjusts to the given level of investment. ${ }^{52}$

\section{Appendix III. Equilibrium saving ratio}

Domar growth model is used to derive for this purpose, where a simple dynamics is introduced in real demand and supply, and the rates of growth of both aggregate saving and output are generated by investment growth:

$$
\begin{aligned}
& \Delta X_{t}=A I_{t} \\
& \Delta Y_{t}=(1 / \sigma) \Delta I_{t} \\
& \Delta X_{t}=\Delta Y_{t}
\end{aligned}
$$

where aggregate output, $X$, is produced through linear production function $X=A K$, and $1 / A$ is the capital/output ratio. Equilibrium requires $x=g$ with $x=\Delta X / X$. Defining $b=\Delta I / Y$ (i.e., the accelerator) and $d \beta=\Delta I / X$, it can be shown that $x=(1+i) d \beta A$ and $g=(b i / \sigma)-1$, where $i=\Delta I / I$. Solving for $\sigma$ yields the (equilibrium) saving ratio that ensures balance between supply and demand growth:

$$
\sigma^{*}=b i /[1+(1+i) d \beta A] \quad[\text { Q.E.D }] \text {. }
$$

\section{Appendix IV. Resource re-appropriation by firms in the circuit process under early industrialism ${ }^{53}$}

Define $X$ as aggregate output selling at market-determined price $p$ and produced by $N$ workers, with productivity $\lambda$ and earning wage $w$. Assuming propensity to consume equal to one, demand from workers is given by $w N$. If $I$ is the amount of output firms want to purchase and $l$ is the share of total labor resources necessary to produce it, then $I=l \lambda N p$. Equilibrium between demand and supply requires

$$
\lambda N p=W N+l \lambda N p
$$

Output price is thus $p=\frac{1}{1-l} \frac{w}{\lambda}$

Defining the profit ratio as the ratio between net output and money spent on production (i.e., the total wage bill)

$$
\pi=\frac{\lambda p-w}{w}=\frac{l}{1-l}
$$

total nominal profit is $P=\pi w N=\frac{l}{1-l} w N$, yielding real profit $\frac{P}{p}=\lambda l N$ 
Note that the real profit equals the output share that firms decided to purchase. The well known Kalecki's proposition is confirmed whereby "workers spend what they earn, while capitalists earn what they spend".

\section{References}

Adams, Dale W., Douglas H. Graham and J.D. Von Pischke, (eds.), 1984, Undermining Rural Development with Cheap Credit (Boulder, Colorado: Westview Press).

Bank for International Settlements, 1998, 68 $8^{\text {th }}$ Annual Report. $1^{\text {st }}$ April 1997-31 $1^{\text {st }}$ March 1998, $8^{\text {th }}$ June (Basle: BIS).

Benson, Bruce L., 1989, The Spontaneous Evolution of Commercial Law, Southern Economic Journal, January, 644-61. Also reproduced in Klein (1997a), 165-90.

1994, Are Public Goods Really Common Pools? Considerations of the Evolution of Policing and Highways in England, Economic Inquiry, April, 249-71.

Benston, George and George Kaufman, 1988, Risk and Solvency Regulation of Depository Institutions: Past Policies and Current Options, Monograph Series in Finance and Economics (New York: New York University Press).

Bossone, Biagio, 1991, Shortage of Global Saving or Shortage of International Liquidity: Should We Forsake the Economics of Lord Keynes?, Il Giornale degli Economisti, No. 7-8, Jul./Aug., 317-46:

1992, Time and Trust in the demand for Money and Assets, International Review of Economics and Business, Vol. 42, No. 10-11, October/November, 793-816.

1996, Sulla 'Scarsita' del Risparmio e sul Rapporto fra Risparmio e Crescita, Quaderni di Economia e Finanza, 5(2), 161-89

No. $2,109-52$.

45 , No. $1,1-26$

1998a, Can Saving Be Scarce?, International Review of Economics and Business, Vol.

Worldwide, Winter 1997-98.

Bresciani Turroni, Costantino, 1936, The Theory of Saving, Economica.

Calomiris, Charles W., 1997, The Postmodern Bank Safety Net. Lessons from Developed and Developing Economies (Washington DC: The American Enterprise Institute Press).

Caprio, Gerard, Jr., 1994, Banking on Financial Reform? A Case of Sensitive Dependence on Initial Conditions, in Caprio et al. (1994), 49-63.

1997, Safe and Sound banking in Developing Countries: We're Not in Kansas Any More, Research in Financial Services: Private and Public Policy, Vol. 9, 79-97. 
Izak Atiyas, and James A. Hanson (eds.), 1994a, Financial Reform. Theory and Experience (Cambridge, Mass.: Cambridge University Press).

Lessons and Strategies, in Caprio et al. (1994a).

1994b, Policy Issues in Reforming Finance:

and Daniela Klingebiel, 1996a, Bank Insolvencies: Cross-Country Experience, Policy Research Working Paper, No. 1620, (Washington, DC: The World Bank).

1996b, Bank Insolvency: Bad Luck, Bad Policy, or Bad

Banking, in Michael Bruno and Boris Pleskovic, Annual World Bank Conference on Development Economics, 1996 (Washington, DC: The World Bank).

Chernow, Ron, 1997, The Death of the Banker. The Decline and the Fall of the Great Financial Dynasties. The Triumph of the Small Investor (New York: Vintage Books, a Division of Random House).

Claessens, Constantijn, 1998, Systemic Bank and Corporate Restructuring: Experiences and Lessons for East Asia, September (Washington, DC: The World Bank).

Asli Demirgüç-Kunt, and Harry Huizinga, 1998, How Domestic Foreign Entry Affect the Domestic Banking Market?, Policy Research Working Paper, No. 1918 (Washington, DC: The World Bank).

-, Simenon Djankov and Larry Lang, 1998, The Asian Financial Crisis: A Corporate Governance Perspective, mimeo (Washington, DC: The World Bank).

, and Tom Glaessner, 1998, The Internationalization of Financial Services in Asia, Policy Research Working Paper, No. 1911, April (Washington, DC: The World Bank).

Dale, Richard, 1996, Regulating the New Financial Markets, prepared for the conference on Globalization: What It Is and Its Implications, May (Sao Paulo).

Davidson, Paul, 1965, Keynes's Finance Motive, Oxford Economic Papers, March.

1991, Finance, Funding, Saving and Investment, in L. Davidson (ed.), The Collected Writings of Paul Davidson, Vol. 1, 365-72 (New York: New York University Press).

De Long, Bradford, 1991, Did J.P. Morgan's Men Add Value? An Economist's Perspective on Financial Capitalism, in Peter Termin (ed.), Inside the Business Enterprise: Historical Perspectives on the Use of Information (Chicago: University of Chicago Press), 205-36. Also reproduced in Klein (1997), 191-223.

Demirgüç-Kunt, Asli, and Ross Levine, 1996, Stock Markets, Corporate Finance, and Economic Growth: An Overview, World Bank Economic Review, Vol. 10, No. 2, May, 223-40.

and Vojislav Maksimovic, 1996, Institutions, Financial Markets, and Firms' Choice of Debt Maturity, (Washington, DC : The World Bank).

and Edward J. Kane, 1998, Deposit Insurance : Issues of Principle, Design and Implementation, Research proposal, March (Washington, DC: The World Bank).

Eisner Robert, 1995, US National Saving and Budget Deficits, in Epstein and Gintis (1995), 109-42. 
Epstein, Gerald. A., and Herbert M. Gintis, 1995, Macroeconomic Policy After the Conservative Era, (Cambridge, UK: Cambridge University Press).

Fuller, Lon L., 1964, The Morality of Law (New Haven: Yale University Press).

Gibson, Michael S., (1993), Long-Term Banking Relationships in general Equilibrium, International Finance Discussion Papers, No. 452 (Washington, DC: Board of Governors of the federal Reserve System).

Glaessner, Thomas, 1993, External Regulation Vs. Self-Regulation: What is the Right Mix? The Perspective of the Emerging Securities Markets of Latin America and the Caribbean, Regional Studies Program Report from the Latin America and the Caribbean Technical Department, June (Washinton, DC: The World Bank).

Goldstein, Morris, 1996, The Case for an International Banking Standard (Washington, DC: International Institute of Economics).

Goodhart, Charles, 1986, Why Do We Need Central Banks?, Temi di Discussione, No. 57, January (Roma: Banca d'Italia).

Gordon, David M., 1995, Putting the Horse (Back) Before the Cart: Disentangling the Macro Relationship Between Investment and Saving, in Epstein and Gintis (1995), 57-108.

Graziani, Augusto, 1984, Moneta senza Crisi, Studi Economici, No. 24, 3-38.

, 1988, Il Circuito Monetario, in Messori (1988).

, 1994, La Teoria Monetaria della Produzione, (Arezzo, Banca Popolare dell'Etruria).

1996, La Toria del Circuito Monetario, (Milano: Jaca Book).

Greenwald, Bruce C., and Joseph Stiglitz, 1991, Information, Finance, and Markets: The Architecture of Allocative Mechanisms, NBER Working Paper, No. 3652, March (New York: National Bureau of Economic Research).

Greif, Avner, 1989, Reputation and Coalitions in Medieval Trade: Evidence on the Maghribi Traders, The Journal of Economic History, Vol. XLIX, No. 4, December. Also reproduced in Klein (1997), 137 64.

Group of Ten Central Banks, 1990, Report of the Committee on Interbank Netting Schemes of the Central Banks of the Group of Ten, November (Basle: Bank for International Settlements).

1996, Settlement Risk on Foreign Exchange Transactions, Report by the Committee on Payment and Settlement Systems March (Basle: Bank for International Settlements).

1998, Reducing Foreign Exchange Settlement Risk: a Progress Report, Report by the Committee on Payment and Settlement Systems, July (Basle: Bank for International Settlements)

Group of Thirty, 1997, Global Institutions, National Supervision and Systemic Risk. A Study Group Report, 10 June (New York: Group of Thirty).

IMF, 1995, Capital Account Convertibility. Review of Experience and Implications for IMF Policies, by Staff Teams headed by Peter J. Quirk and Owen Evans, Occasional Paper No. 131, October (Washington, DC). 
---, 1998a, Toward a Framework for Financial Stability, prepared by a Staff Team led by David

Folkerts-Landau and Carl-Johan Lindgren, January (Washington, DC: International Monetary Fund).

-_-, 1998b, Capital Account Liberalization. Theoretical and Practical Aspects, by a Staff Team led by Barry Eichengreen and Michael Mussa (Washington, DC: International Monetary Fund).

J.P. Morgan, 1997, Introduction to CreditMetrics. The Benchmark for Understanding Credit Risk, April 2 (New York).

Hellmann, Thomas and Kevin Murdock, 1995, Financial Sector Development Policy: The Importance of Reputational Capital and Governance, Stanford Graduate School of Business Research Paper 1361, December (Stanford: Stanford University).

and Joseph Stiglitz, 1994, Addressing Moral Hazard in Banking: Deposit Rate Control vs. Capital Requirements, mimeo, Stanford University.

Financial Restraint, Stanford Graduate School of Business Research Paper, No. 1354, July (Stanford: Stanford University).

Paradigm in Aoki, Masahiko, Hyung-Ki Kim and Masahiro Okuno-Fuiiwara (eds.), The Role of Government in East Asian Economic Development. Comparative Institutional Analysis, 163-2 7 (Oxford: Clarendon Press).

Honohan, Patrick, 1997, Banking System Failures in Developing and Transition Countries: Diagnosis and Prediction, BIS Working Paper, No. 39 (Basle: Bank for International Settlements).

Keehn, Silas, 1992, Banking on the Balance: Powers and the Safety Net, A Proposal, Working Paper (Chicago: Federal Reserve Bank).

Keynes, John Maynard, 1936, The General Theory of Income, Interest and Money, Harcourt, Brace and World, New York, 1964.

Journal, 47, June, 241-52.

Journal, 47, Dec., 229-33.

King, Robert, and Ross Levine, 1993, Finance and Growth: Schumpeter Might Be Right, Quarterly journal of Economics, August, 108(3), 717-38.

Klapper, Leora, 1998, Short-Term Collateralization: Theory and Evidence, mimeo.

Klein, Daniel B. (ed.), 1997a, Reputation. Studies in the Voluntary Elicitation of Good Conduct, (Ann Arbor: The University of Michigan Press).

133.

La Porta, Rafael, Florencio Lopez-de-Silanes, Andrei Shleifer and Robert Vishny, 1996, Law and Finance, , NBER Working Paper, No. 5661, July (Cambridge, Mass.: National Bureau of Economic Research). 
Determinants of External Finance, Journal of Finance, 52(3), July, 1131-50.

1997, Legal

Levine, Ross, 1997, Financial Development and Economic Development: Views and Agenda, Journal of Economic Literature, June, 35, 688-726,.

, Norman Loayza and Thorsten Beck, 1998, Financial Intermediation and Growth:

Causality and Causes, June, mimeo.

Lindgren, Carl-Johan, Gillian Garcia and Matthew I. Saal, 1996, Bank Soundness and Macroeconomic Policy (Washington, DC: International Monetary Fund).

Jappelli, Tullio and Marco Pagano, 1991, Information Sharing in Credit Markets, CEPR Discussion Paper, No. 579, October (London: Centre for Economic Policy Research).

Martinez Peria, Maria Soledad and Sergio L. Schmukler, 1998, Do Depositors Punish Banks for Bad Behavior?: Examining Market Discipline in Argentina, Chile, and Mexico, manuscript (Washington, DC: The World Bank).

McDonough, William J., 1990, The Case for Price Stability, Remarks by the President of the Federal Reserve Bank of New York before the 39th International Congress of the Association Cambiste The Financial Market Association Internationale, 30 May (Toronto).

Messori, Marcello (ed.), 1988, Moneta e Produzione, (Torino: Einaudi).

Minsky, Hyman P., 1990, Schumpeter e la Finanza, in Biasco Salvatore, Alessandro Roncaglia and Michele Salvati, Istituzioni e Mercato nello Sviluppo Economico. Saggi in Onore di paolo Sylos Labini (Bari: La Terza).

Nickerson, David, 1995, Governance and Efficiency in Emerging Financial Markets, The Journal of International Trade and Economic Development, December, 261-81.

OECD, 1993, The Role of Financial Institutions in the Transition to a Market Economy, Study of the Group of Financial Experts on Eastern European Countries, Committee on Financial Markets, 29 October (Paris: Organisation for Economic Co-operation and Development).

Ostrom, Elinor, 1990, Governing the Commons. The Evolution of Institutions for Collective Action. (Cambridge, UK: Cambridge University Press).

Padoa-Schioppa, Tommaso, 1996, Address to the 9th International Conference of Banking Supervisors, Stockholm, 12-14 June, Documenti No. 533, July (Roma: Banca d'Italia).

Pahwa, H. P. S. and B. K. Pahwa, 1998, Law Relating to Non-Banking Financial Companies (Lucknow: Vinod Law Publications).

Prowse, Stephen, (1998), Corporate Governance: Emerging Issues and Lessons from East Asia, September (Washington, DC: The World Bank).

Ryser, Marc, 1997, Sanctions Without Law: The Japanese Financial Clearinghouse Guillotine and its Impact on Default Rates, in Klein (1997), 225-40.

Schiantarelli, Fabio, Izak Atiyas, Gerard Caprio, Jr., John Harris, and Andrew Weiss, 1994, Credit Where it is Due? A review of the Macro and Micro Evidence on the Real Effects of Financial Reform, in Caprio (1994a). 
Smithson, Charles W., and Clifford W. Smith, with D. Sykes Wilford, 1995, Managing Financial Risks. A guide to derivative products, financial engineering, and value maximization (New York: Mc Graw Hill).

Solow, Robert, 1956, A contribution to the Theory of Economic Growth, Quarterly Journal of Economics, 70, 65-94. 1994, Lezioni Sulla Teoria della Crescita Endogena (Roma: Nuova Italia Scientifica).

Stiglitz, Joseph E., 1993, Peer Monitoring and Credit Markets, in K. Hoff, A. Braverman, and Joseph E. Stiglitz (eds.), The Economics of Rural Organizations. Theory, Practice and Policy, 70-86 (Oxford: Oxford University Press).

Vittas, Dimitri, 1992, Financial Regulation: Changing the Rules of the Game (Washington, DC: The World Bank).

Vogel, Robert C., 1984, Savings Mobilization: The Forgotten Half of Rural Finance, in Adams et al. (1984), 248-65.

Von Pischke, J.D., 1991, Finance at the Frontier. Debt Capacity and the Role of Credit in the Private Economy (Washington, DC: Economic Development Institute of the World Bank).

Wall, Larry D, 1989, A Plan for Reducing Future Deposit Insurance Losses: Puttable Subordinated Debt, Federal Reserve Bank of Atlanta Economic Review, July/August, 2-17.

World Bank, 1998, Argentina. Financial Sector Review, July 31, (Washington, DC: The World Bank).

Yaron, Jacob, Benjamin P. McDonald, and Gerda L. Piprek, 1997, Rural Finance. Issues, Design, and Best Practices (Washington, DC: The World Bank).

\footnotetext{
${ }^{1}$ For a presentation of monetary circuit theory, see Graziani, (1984, 1988, 1994, 1996). Messori (1988) offers a collection of important contributions from circuit theorists. Monetary circuit theory has major proponents in Europe - most notably in France and Italy - where different groups of scholars are active under B. Schmitt, A. Parguez, and F. Poulon, C. Benetti, J. Cartelier, A. Graziani, and M. Messori, to cite some of the major names. On this side of the Atlantic, Marc Lovoie is a leading circuit scholar from Canada. In the United States, a circuit-based interpretation of the saving-investment process was propounded long ago, and later on reiterated, by Paul Davidson $(1965,1991)$.

${ }^{2}$ For an analysis of the role of trust in the theory of money and finance, based on a neoclassical model, see Bossone (1992, 1997).

${ }^{3}$ The model is a revised version of a previous, simpler circuit model (Bossone 1996, 1998a). Monetary circuit theorists define Davidson's concepts of financing and funding as, respectively, initial financing and final financing (See Graziani, 1984).

${ }^{4}$ Monetary circuit theory, in particular, stresses the role of banks in sustaining the circuit process by providing new liquidity (through loan roll-overs) to firms that have failed to re-appropriate money spent in unrealized production.

${ }^{5}$ The introduction of a middleman agent is necessary in order to frame agents' interactions through interhousehold trade.

${ }^{6}$ The issue of collateral for short term lending is studied in a recent work by Klapper (1998).

${ }^{7}$ The proceeds of the investment financial institutions should partly feed into payments for inputs as income of input suppliers, and only profits could in fact be saved. However, since the income of input suppliers would have the same destination and use of corporate income, they may be left out of the model
} 
without loss of generality or alteration of results. For the same reason, commercial banks are assumed not to bear costs.

${ }^{8}$ As $y_{F}$ is linear in $L F$, investment financial institutions would increase their current income by increasing the supply of funds, apparently in contradiction with the above assumption on the $L F$ supply schedule. Note, however, that in a repeated-game situation, where long-term income depends also on reputation, financial institutions have to be sensitive to the risk of supplying funds to weak companies that would later fail to comply with their obligations or prove unable to ensure a satisfactory investment return. Their supply schedule must thus reflect the risk factors, as assumed above.

${ }^{9}$ This function was well recognized already in the thirties by Bresciani Turroni (1936).

${ }^{10} \mathrm{In}$ terms of the model described above, if the investment financial institutions ration the supply of funds to investing companies, they correspondingly "ration" their demand for savings, thus forcing savers to hold larger shares of on-interest bearing bank deposits. A lower return on saving, in turn, feeds into households' Euler conditions and lead households to revise their optimal intertemporal consumption plan. As the model shows (see Appendix 2), this would change the composition of aggregate saving but not its level.

${ }^{11}$ This argument holds for open economies as well and refers, in this case, to world saving: domestic investment adds to the pool of world savings thorough the balance of payments, whereas changes in domestic savings cannot alter world saving (see also footnote 23). For an analysis of the relationship between global investment and saving, see Bossone (1991, 1998a).

${ }^{12}$ As Keynes (1937b) remarked, “... The investment market can become congested through shortage of cash. It can never become congested through shortage of saving. This is the most fundamental of my conclusions in this field." (p. 222).

${ }^{13}$ This sub-section draws on Graziani (1988), Minsky (1990) and Chernow (1997).

${ }^{14}$ On banks' incentives to long-term contracts, see Gibson (1993).

${ }^{15}$ Note from Figure 1 that, under severe information and trust limitations leading to long-term fund rationing, investment supply (and saving) would tend to adjust toward the point where enough long-term funding is available. Eventually, investment demand as well would converge to the constrained position as the investing companies would find themselves unable to signal their "true" demand through the price mechanism. But, clearly, the result would be a sub-optimal equilibrium, since equality would hold at a point where $\rho>r_{L}^{-}$, and the economy would be under-investing. Financial sector reform should thus aim to reduce transaction costs associated with incomplete trust and produce information necessary to price risk accurately, so as to shift the long-term fund supply schedule to the point where capital efficiency is optimized.

${ }^{16}$ Most of the statistical evidence and comments reported in the following paragraphs are drawn from Gerald Caprio, Jr., and Constantijn Claessens, 1990, The importance of the Financial System for Development, background paper for Board discussion (Washington, DC: The World Bank), unpublished. I am indebted to the Authors for permitting me to use their material.

${ }^{17}$ For example, if Zaire in 1970 had increased its share of domestic credit allocated by banks from only $26 \%$ of total credit to the average for developing countries in that year $(57 \%)$, it would have grown about $0.9 \%$ faster per annum. Greater financial sector development was found to raise growth both by increasing capital accumulation and importantly by raising productivity.

${ }^{18}$ Interestingly, in the Indonesian case it was also true that financial reforms led to more credit for smaller firms, who previously been had been more constrained in obtaining funding.

${ }^{19}$ A detailed reconstruction of the crisis is provided in Bank for International Settlements (1998). For recent studies of the crises, see the proceedings of the CEPR/World Bank Conference on Financial Crises: Contagion and market Volatility, London, 8-9 May 1998, and the contributions to the World Bank's Global Economic Prospects '98: The Aftermath of the Asian Crisis, Washington DC, 13-14 May 1998.

${ }^{20}$ Part $I I$ is a revised version of the paper Strengthening Financial Systems in Developing Countries: The Case for Incentives-Based Financial Sector Reforms, co-authored with Larry Promisel for the Seminar Strengthening Banking Systems, IMF-World Bank Annual Meetings, October 3, 1998, Washington DC. ${ }^{21}$ The term "self-policing", which will recur several times in this text, refers to the capability of a system of private-sector agents to induce compliance with common rules of conduct from each agent, without resorting to exogenous rule enforcing mechanisms. Self-policing can either be the result of agents having incentives to undertake behavior that conforms to the collective interest, or the outcome of agents having an 
incentive to mutually monitor behavior. Suggestively, Klein, 1997a (Introdurtion), talks of self-policing being the work of an "invisible eye".

(i)

${ }^{22}$ The reputational capital of a financial institution consists of a complex set of variables that signal at any point in time the probability of the institution ability and willingness to fulfil its obligations. The most relevant variables are: the institution's long-term mission and strategy, market presence, financial strength and profitability, organizational and governance, capacity to manage financial and operational risks, past compliance with legal and financial obligations, quality of service and advice delivered, quality of projects financed, quality and ethics of management and personnel, transparency. The gains to be derived from the buildup of reputational capital can provide an effective incentive if the institution is owned and run by agents who are responsible for: : $s$ market performance and who are rewarded accordingly. Thus, well defined legal property rights, private ownership, and market competition are essential prerequisites for the success of incentive-based financial sector reforms.

${ }^{23}$ This observation holds true also in the case of open economies as investment adds to the world pool of savings through the balance of payments, although not necessarily to domestic saving. To the extent that domestic financial institutions can have free access to the world market for long-term capital, the "scarcity" of saving is resolved for an open economy.

${ }^{24}$ One of many examples can be drawn from the literature on credit risk management. By treating all its credit exposures (across all outstanding financial contracts) with a single counterparty as components of a single portfolio, price correlations underlying the contracts, or the existence of a netting settlement agreement with the counterparty, or the co-presence in the portfolio of derivative contracts with offsetting claims on income flows, can reduce the total portfolio exposure considerably below the sum of the exposures on individual contracts. As a result, the capital to be allocated to the expected portfolio loss is less than the capital that would have to be immobilized if the exposures were treated separately. See Smithson et al. (1995).

${ }^{25}$ The example of CreditMetrics in the area of credit risk management is illustrative. As the interest of regulators in limiting banks' credit risk on derivatives has grown considerably over the recent years, banks have introduced internal credit limit systems for counterparties. As it turns out, the methodologies to calculate such limits are quite ad hoc and often lead to over- or under-use of bank capital. Eventually, one market agent has developed and commercialized a methodology (i.e., CreditMetrics) that replaces exogenous limits with endogenously-determined, credit risk-based, optimal credit exposures. These optimal values are obtained by equating the return form expanding the exposure incrementally with the additional risk associated with the increase in the exposure.

${ }^{26}$ See Hellmann and Murdock (1995), and Hellmann, Murdock and Stiglitz (1994, 1995, 1996).

${ }^{27}$ Banks may also seek to attract large individual depositors. In this case, they would not need to rely on public knowledge. However, it should not be difficult for supervisors to identify such cases when inspecting banks.

${ }^{28}$ These recommendations were pointed to the author by Prof. Charles Calomiris.

${ }^{29}$ As for any promisor, the incentive for the government to honor the guarantee may weaken over time, as well as the risk of it being unable to do so due to unexpected contingencies. To the extent that the bailout promise is credible - both in principle and in practice - its incentive may be strong enough to lead well informed lenders to expand their short-term exposure even if they have full knowledge of unsustainable macroeconomic conditions. Credit flows would be discontinued if the market perceived the bailout promise to be no longer credible.

${ }^{30}$ On this argument see the recent work from the IMF (1998b).

${ }^{31}$ See the Report of the Committee on banking Sector Reforms, April 1998 (also know as the second Narasimham report).

${ }^{32}$ For a review of the many and variegated experiences with capital controls, see IMF (1995), Ch. VII and World Bank (1997), Ch. 6.

${ }^{33}$ The principle of combining regulatory measures with incentives was first articulated in Benston and Kaufman (1988) in the context safety nets. See also discussion in Goldstein (1996).

${ }^{34}$ Note, however, that to the extent that the market rewards a strong capital base, banks have an incentive to hold capital in excess of the minimum requirements; this does already occur in a number of countries, including developing ones. Banks in Argentina, Honk Kong, Singapore hold capital asset ratios of 15 to 19 percent. 
${ }^{35}$ In financial risk-management terminology, economic capital is the capital required to back the exposure on an outstanding financial contract with a counterparty. It is estimated as the product of the expected loss on the contract, due to counterparty default on obligations, and the probability of counterparty default (adjusted for the ratio of loss recovery). The loss is estimated as the sum of two components: the market replacement value of the contract at the time of estimation (current loss), and the maximum possible loss from the time of estimation to the time of contract settlement (potential loss), determined under specific (worst case scenario) hypotheses regarding the price distributions underlying the contract. The estimation of economic capital can be further refined by considering possible time profiles of the counterparty default probability as can be learned from past statistical evidence. Also, as noted earlier, portfolio techniques can be applied to improve the efficiency of economic capital allocations.

${ }^{36}$ These points were suggested to the author by Prof. Charles Calomiris.

${ }^{37}$ On central bank lending and on conservatorship, see IMF (1998a). On issues relating to conservatorship, see World Bank (1998).

${ }^{38}$ Caprio and Klingebiel (1996a, 1996b) and Lindgren et al. (1996) provide evidence of the relevance of the moral hazard problem in financial systems both in industrial and developing countries.

${ }^{39}$ An in-depth and multi-purpose research work on deposit insurance is being carried out at the World Bank by Asli Demirgüç-Kunt and Edward J. Kane (1998).

${ }^{40}$ See Benson (1989, 1994), Greif (1989), Ryser (1997). Interestingly, the examples drawn from history show that spontaneous cooperative arrangements have developed within the private sector in the absence of government action to overcome the constraints to profitable international business from limited information and incomplete trust: the prospects of long-term profits drove agents to establish self-policing rules that made those prospects possible by reducing the costs of transacting. More recently, with globalization strongly reducing the effectiveness (and increasing the externalities) of domestic policymaking, governments have recognized the importance of international cooperation, and actively promote international private-sector cooperative arrangements at the industry levels. In the area of international finance, a notable example is provided by the implementation of the strategy of the G10 Central Banks for the reduction of settlement risk in foreign exchange transactions (see Group of Ten Central Banks 1996, 1998 and Bossone 1998b).

${ }^{41}$ In his empirical investigation, Ostrom, cit., observes that all successful cases of self-policing arrangements featured a number of operational principles: 1) clearly defined boundaries and membership; 2) congruence between members' resource appropriation and provisions; 3 ) member participation in defining operational rules; 4) monitoring; 5) graduated sanctions; 6) conflict-resolution mechanisms; 7) members' right to devise own institutions unchallenged by government; 8) in the case of larger systems, activities were organized in multiple layers of nested enterprises. Certain conditions are necessary for selfpolicing arrangements to emerge. First, a relationship of reciprocity must result from a deliberate and voluntary agreement of the parties involved: they are those who create the arrangement. Second, reciprocity must be perceived by members as involving fair exchanges of values: symmetry is necessary for the arrangement to endure. Third, the relationship between members must be reversible: each member may be called on by others to provide, and may equally call on others to provide, the services agreed under the arrangement. A fourth fundamental condition is ownership of rewards: each member must be in a position to own the (positive or negative) rewards from her action. Members must be held responsible and accountable for their action, and must therefore be able to appropriate the benefits and costs associated with their action. If these conditions are met, the agents perceive potential gains from tying mutual bonds with each other by entering into (formal or informal) arrangements, and potential costs from contravening such arrangements once entered into. The first three conditions replicate Fuller's (1964) conditions for the recognition of (legal or moral) duty from individuals affected by duty (see also Benson, 1997), and are here adapted to the context of self-policing arrangements.

${ }^{42}$ In some arrangements, admission rules require new member candidates to be introduced and sponsored by senior members. The latter act as guarantors of the candidates' reputation. As the reputation of senior members is at stake, this mechanism puts pressure on them to be confident enough about the true quality of the sponsored candidates.

${ }^{43}$ As the examples from history show, self-policing arrangements have successfully governed themselves even in the absence of coercive power of Government. Members formed their own courts to adjudicate disputes, and courts' decisions were accepted by members under the threat of reputational capital losses. "Private" adjudication schemes guaranteed speed, informality and technical competence. The adjudicative 
procedures and the rules adopted by the courts were designed to facilitate commercial interactions. The importance of legal certainty for growth is assessed in recent studies by La Porta et al. (1996, 1997, and by Levine et al., (1998).

${ }^{44}$ See, in this respect, the approach adopted by the Group of Ten Central Banks (1990) for the oversight of multilateral netting payment and settlement systems.

${ }^{45}$ Martinez Peria and Schmuckler (1998) suggest that information greatly enhances market discipline in the banking sector by allowing depositors to select banks according to their financial strength, quality of services, portfolio diversification and risk composition.

${ }^{46}$ The monthly report "Financial Information' of the Chilean Superintendency of Banks and Financial Institutions provides an example of public disclosure of bank credit risk (see Honohan, 1997).

${ }^{47}$ These points were suggested to the author by Prof. Charles Calomiris.

${ }^{48}$ It is assumed that household-shopkeeper $i$ does not hold inventory, so that $k$ 's changes in consumption reflect directly into $f$ 's sales. Assuming inventory stocks would not alter the results of the model.

${ }^{49}$ These results show the existence of an inverse relationship between household and corporate savings for any given level of investment. The inverse relationship would as well apply to public and private sector savings, and it would hold independently of compliance from individual agents with optimal rules or of Ricardian equivalence effects. For empirical supporting evidence, see Eisner (1995).

${ }^{50}$ This occurs if agent $i$ foresees correctly $k$ 's intertemporal allocation decisions and holds onto her optimal rule.

${ }^{51}$ In a model with agents' interaction, optimality of individual saving decisions implies compliance with a dual condition: 1) ex-post individual savings must equal ex-ante individual savings, and 2) the sum of individual ex-ante savings must equal ex-ante investment in the aggregate. Whereas condition 2) is always in force, no market mechanism ensures condition 1) if the agents fail to internalise the externalities produced by interactions within their intertemporal allocation decisions.

52 When interactions are considered, the price mechanism is not by itself sufficient to ensure coordination (and, thus, optimality) of individual saving decisions, as these generate externalities that are not internalized by the "price" of saving. For coordination to succeed, each agent should ideally incorporate in her saving plan the ex-ante saving decisions of all other agents, and all should be willing to adjust their desired savings until all individual saving plans become mutually consistent. But the point is: which incentive mechanisms would drive such coordination process, and why, in the absence of appropriate incentives, would the agents be willing to change their plans even if they had all the necessary information? ${ }^{53}$ This appendix draws on Graziani (1988). 


\section{Policy Research Working Paper Series}

Title

WPS2007 Regional Integration Arrangements: Static Econornic theory, Quantitative Findings, and Policy Guldelines

WPS2008 Volatility and Contagion in a Financially integrated World: Lessons from East Asia's Recent Experience
Author

Dean A. DeRosa

Pedro Alba

Amar Bhattacharya

Stijn Claessens

Swati Ghosh

Leonardo Hernandez

WPS2009 Poverty and the Economic Transition How Do Changes in Economies of Scale Affect Poverty Rates for Different Households?
Peter Lanjouw Branko Milanovic Stefano Paternostro Evidence from the Republic of Korea Giovanni Ferri

WPS2011 Measuring Poverty Using Qualitative Menno Pradhan
Perceptions of Welfare

WPS2012 Export Quotas and Policy Constraints Sanjay Kathuria in the Indian Textile and Garment Industries

WPS2013 A New Database on Investment and Capital for Agriculture and Manufacturing

WPS2014 Land Institutions and Land Markets

WPS2015 The Mechanics of Progress in Education: Evidence from CrossCountry Data

WPS2016 Financial Services for the Urban Poor: South Africa's E Plan

WPS2017 Corporate Growth, Financing, and Risks in the Decade before East Asia's Financial Crisis

WPS2018 Prerequisites for a DevelopmentOriented State in the Democratic Republic of the Congo
Date

November 1998

November 1998

November 1998

November 1998

Contact for paper

L. Tabada 36896

D. Fischer 38656

P. Sader 33902

November 1998

November 1998 Anjali Bhardwaj

Al Crego Donald Larson

Rita Butzer

Yair Mundiak

Klaus Deininger

Gershon Feder

Alain Mingat

Jee-Peng Tan

November 1998

M. Greaves 81876

P. Sader 33902

L. Tabada 36896

November 1998

P. Kokila 33716

November 1998

M. Fernandez 33766

A. Poghosyan 30898

Jo Ann Paulson James McAndrews

November 1998

A. Thornton 80408

Stijn Claessens

Simeon Djankov

Larry Lang

November 1998

R. Vo

33722

Mondonga M. Mokoli Hans P. Binswanger
November 1998

H. Binswanger 31871 


\section{Policy Research Working Paper Series}

\section{Title \\ Author \\ Date \\ Contact}

\begin{tabular}{|c|c|c|}
\hline & Title & Author \\
\hline WPS2019 & $\begin{array}{l}\text { The Effects on Developing Countries } \\
\text { of the Kyoto Protocol and Carbon } \\
\text { Dioxide Emissions Trading }\end{array}$ & $\begin{array}{l}\text { A. Denny Ellerman } \\
\text { Henry D. Jacoby } \\
\text { Annelene Decaux }\end{array}$ \\
\hline WPS2020 & $\begin{array}{l}\text { Trade Liberalization, Fiscal } \\
\text { Adjustment, and Exchange Rate } \\
\text { Policy in India }\end{array}$ & $\begin{array}{l}\text { Delfin S. Go } \\
\text { Pradeep Mitra }\end{array}$ \\
\hline WPS2021 & $\begin{array}{l}\text { Balance, Accountability, and } \\
\text { Responsiveness: Lessons about } \\
\text { Decentralization }\end{array}$ & Anwar Shah \\
\hline WPS2022 & $\begin{array}{l}\text { The Implications of Foreign Aid } \\
\text { Fungibility for Development } \\
\text { Assistance }\end{array}$ & $\begin{array}{l}\text { Shantayanan Devarajan } \\
\text { Vinaya Swaroop }\end{array}$ \\
\hline WPS2023 & $\begin{array}{l}\text { Capital Inflow Reversals, Banking } \\
\text { Stability, and Prudential Regulation } \\
\text { in Central and Eastern Europe }\end{array}$ & $\begin{array}{l}\text { Samuel Talley } \\
\text { Marceio M. Giugale } \\
\text { Rossana Polastri }\end{array}$ \\
\hline WPS2024 & $\begin{array}{l}\text { Re-Engineering Insurance } \\
\text { Supervision }\end{array}$ & Lawrie Savage \\
\hline WPS2025 & $\begin{array}{l}\text { Dynamic Capital Mobility, Capital } \\
\text { Market Risk, and Exchange Rate } \\
\text { Misalignment: Evidence from Seven } \\
\text { Asian Countries }\end{array}$ & Hong G. Min \\
\hline
\end{tabular}

December 1998

T. Tourougui 87431

December 1998

C. Bernardo 31148

December 1998

A. Shah 37687

December 1998

C. Bernardo 31148

December 1998

M. Geller 85155

December 1998

H. Arbi 34663

December $1998 \quad$ K. Labrie 31001 